\title{
THE ALLOCATION OF COMPETENCE IN ASYLUM PROCEDURES UNDER EU LAW: THE NEED TO TAKE THE DUBLIN BULL BY THE HORNS
}

\author{
MARCELLO DI FILIPPO' \\ University of Pisa \\ marcello.difilippo@unipi.it
}

Cómo citar/Citation

Di Filippo, M. (2018).

The allocation of competence in asylum procedures under EU law:

The need to take the Dublin bull by the horns. Revista de Derecho Comunitario Europeo, 59, 41-95. doi: https://doi.org/10.18042/cepc/rdce.59.02

\begin{abstract}
The aim of the Dublin system is to prevent positive and (most commonly) negative conflicts of competence regarding the determination of a peculiar prsonal status, by rapidly identifying a single responsible Member State (MS). This article discusses the performance of this set of rules, drawing inspiration from other areas
\end{abstract}

1 Professor of International Law and Coordinator of the Observatory on European Migration Law, University of Pisa (http://migration.jus.unipi.it). The research work for this article has been greatly facilitated by the funds awarded to the author in the framework of the Jean Monnet Module "EU Migration Law, Human Rights and Democratic Principles" (2015-2018). The author is grateful to David J. Cantor, Philippe De Bruycker, Ornella Feraci, Giorgio Gaja, Marco Gestri, James C. Hathaway, Sara Iglesias Sánchez, Laurens Jolles, Simone Marinai, Gianfranco Schiavone and to the anonymous referees of this journal for their thoughtful comments on earlier drafts of this article. The responsibility for possible omissions or errors rests solely with the author. 
where a need for coordination of State powers arises and aims to ascertain whether the current Dublin III Regulation complies with the relevant guidelines and principles spelled out in EU primary law, in the Geneva Convention, and in the international regime on Search and Rescue at Sea.

After having determined the unsatisfactory outcomes of the present rules, the essay takes a different approach, partially echoed in a report recently adopted by the European Parliament on the reform of the Dublin system and based on several indispensable and mutually reinforcing elements: an enhanced recourse to connecting criteria inspired by a genuine link approach; the introduction of a permanent system of mandatory shares of applications, according to a proper reading of art. 80 TFEU; the adoption of reasonable incentives for States and applicants to fully participate in the system (including a qualified freedom of movement for work purposes); the simplification of the procedures. In doing so, the article takes the recent case law of the European Court of Justice into due account.

\section{Keywords}

Asylum; European Union; Dublin regulation; competence; fair sharing of responsibilities.

\section{LA ASIGNACIÓN DE COMPETENCIA EN LOS PROCEDIMIENTOS DE ASILO BAJO EL DERECHO DE LA UE: LA NECESIDAD DE COGER EL TORO DE DUBLÍN POR LOS CUERNOS}

\section{Resumen}

La finalidad del sistema de Dublín es prevenir los conflictos positivos y negativos de competencia sobre la determinación de un peculiar estatuto personal, identificando de forma inmediata el Estado miembro responsable. Este artículo analiza los logros de este conjunto de reglas, sacando inspiración de otras áreas donde emerge la necesidad de coordinar la atribución de poderes estatales y determinando si el vigente Reglamento Dublín III cumple con los principios fundacionales del SECA, la Convención de Ginebra y el régimen internacional de búsqueda y salvamento marítimo.

Tras haber averiguado los límites de funcionamiento de la presente construcción, el artículo hace hincapié en un enfoque diferente, acogido parcialmente en un reciente informe del Parlamento Europeo sobre la revisión del sistema Dublín y basado en varios elementos indispensables y complementarios: el mayor empleo de factores de conexión inspirados por un vínculo efectivo (genuine link); la introducción de un sistema permanente de cuotas obligatorias, de acuerdo con una interpretación adecuada del art. 80 TFUE; la adopción de incentivos razonables para los Estados y los solicitantes con el fin de involucrarlos plenamente en el funcionamiento del sistema (incluyendo una libre circulación cualificada por motivos laborales); la 
simplificación de los procedimientos. Finalmente, se tendrá en cuenta la reciente jurisprudencia del Tribunal de Justicia de la Unión Europea.

\section{Palabras claves}

Asilo; Unión Europea; Reglamento de Dublín; competencia; reparto equitativo de la responsabilidad.

\section{L'ATTRIBUTION DE COMPÉTENCE DANS LES PROCÉDURES D'ASILE EN VERTU DU DROIT DE L'UNION EUROPÉENNE : LA NÉCESSITÉ DE PRENDRE LE TAUREAU DE DUBLIN PAR LES CORNES}

\section{Résumé}

Le but du système Dublin est de déterminer rapidement l'État membre responsable de l'examen des demandes d'asile en tranchant les éventuels conflits de compétence positifs ou négatifs concernant ce statut personnel particulier. Tout d'abord, l'article analysera l'efficacité de cet ensemble de règles compte tenu des enseignements tirés dans autres domaines de coopération internationale, où des critères de compétence sont spécifiés et vérifient si l'actuel Règlement Dublin III se conforme aux lignes directrices pertinentes et aux principes énoncés dans le droit primaire de l'UE, la Convention de Genève et le régime international de recherche et de sauvetage en mer.

Après avoir déterminé les résultats insatisfaisants du système légal courant, l'article adopte une approche différente, soutenu partiellement par le rapport adopté au Parlement européen concernent la révision du règlement Dublin. Il s'agit de combiner plusieurs éléments indispensables et complémentaires : un recours accru aux critères de compétence fondés sur des liens substantiels ; l'introduction d'un système permanent de quotas obligatoires selon une interprétation appropriée de l'art. $80 \mathrm{du}$ TFUE ; l'adoption de mesures incitatives acceptables pour les Etats et les demandeurs d'asile (y compris une partielle liberté de séjour pour des raisons de travail) ; la simplification des procédures. La récente jurisprudence de la Cour de justice est également prise en compte.

\section{Mots clés}

Asile; Union européenne; compétence; règlement de Dublin; partage équitable de responsabilités. 


\section{SUMMARY}

I. INTRODUCTION. II. THE DUBLIN SYSTEM AS A TOOL FOR COORDINATING STATES' COMPETENCE AND THE TRENDS EMERGING FROM OTHER FIELDS IN WHICH DELIMITATION OF STATES' POWER IS DEALT WITH. III. THE DEFICIENCIES OF THE DUBLIN SYSTEM IN ITS BROADER LEGAL CONTEXT: 1. The guiding principles of the CEAS and the inability of the Dublin system to comply with them. 2. The underlying tension with the Geneva Convention. 3. The side effects on the search-and-rescue regime at sea. IV. THE WAY FORWARD: THE NEED TO RECONSIDER ALLOCATION CRITERIA ON A PRINCIPLED BASIS: 1. Family relations and their enhanced role in a displacement setting. 2. The "authorisation principle" and the country of first irregular entry: 2.1. A connecting factor whose rationale is far from rational. 2.2. The signals coming from the Court of Justice: a sober push for a change. 3. Party autonomy: a criterion not fully suited for asylum matters. 4. The "closest connection" criterion or the genuine link approach: 4.1. Its possible meaning in asylum procedures. 4.2. The risk of new imbalances and the need to give teeth to article 80 TFEU. 4.3. Procedural issues and standard of proof. V. CONCLUSION. BIBLIOGRAPHY.

\section{INTRODUCTION}

The international protection of asylum seekers has always been challenging, but the facts that have occurred in recent years around the European neighborhood have raised an unprecedented debate among policymakers, public opinion and academics. One of the most debated issues concerns the perceivably unequal distribution of burdens across the international community, with some countries absorbing high shares of displaced persons and others doing little if nothing. The discussion on the degree of the actual commitment of States to international protection is not new ${ }^{2}$, and it may be articulated on a global level or on a regional one, especially if a common area

2 From this perspective, it is striking to note that the vast majority of refugees are hosted in States located close to the countries of origin and often characterised by low-income economies. For a discussion of this topic, see, for instance, Dowd \& McAdam (2017); Hathaway \& Neve (1997); Milner (2016); Wall (2017). 
of free movement and border control is in force. In this article, the latter focus will be adopted, taking the EU as a significant benchmark for critical reasoning on the allocation of State responsibility for hosting asylum seekers.

It is well known that the launch of the Schengen area included the adoption among the then members of the European Communities of common criteria for allocating to one of them (and, by way of principle, to only one of them) the competence to determine the asylum claim and subsequently afford protection to the successful applicant. Such criteria were originally specified in the Convention signed in Dublin on 15 June 1990 by all the Member States and in the Convention implementing the Agreement of Schengen (arts. 28-38), signed in Schengen on 19 June 1990 by some Member States. Those rules were later replaced by EC Regulation No. 343/2003 (the Dublin II Regulation) and, lastly, by EU Regulation No. 604/2013 (the Dublin III Regulation).

Following the publication of many critical studies ${ }^{4}$, the acute crisis in the effectiveness of the Common European Asylum System (CEAS) provoked by the events that occurred between 2013 and 2016, and the exhortations coming from various actors (including the European Council ${ }^{5}$ and the European Parliament ${ }^{6}$ ), in May 2016, the European Commission put forward a proposal $^{7}$ to revise the Dublin III Regulation (the Dublin IV proposal).

I will not assess in detail the shortcomings of the Dublin system, which have been widely documented in the relevant literature ${ }^{8}$, and will not go into

3 Regulation (EU) 604/2013 of the European Parliament and of the Council, of 26 June 2013, establishing the criteria and mechanisms for determining the Member State responsible for examining an application for international protection lodged in one of the Member States by a third-country national or a stateless person (recast) (OJ L 180, of 29 June 2013, p. 31).

4 See, inter alia, Del Valle Gálvez (2016a); Feraci (2013: 6-7, 36-37); Fratzke (2015); Garlick (2016); Guild et al. (2015); Maiani (2016a); Mouzourakis (2014); Peers (2015).

5 See European Council, “Conclusions of 15 October 2015”, EUCO 26/15, 33.

6 See European Parliament, "Resolution of 12 April 2016 on the situation in the Mediterranean and the need for a holistic EU approach to migration (2015/2095(INI))", A8-0066/2016, 12-4-2016, \$\$ 33-38.

7 See "Proposal for a Regulation establishing the criteria and mechanisms for determining the Member State responsible for examining an application for international protection lodged in one of the Member States by a third-country national or a stateless person (recast)", COM (2016) 270 final, 4-5-2016.

8 In addition to the references indicated in footnote 3, see also Den Heijer et al. (2016: 610-614); ICF International (2015); ICF International (2016); Maiani (2016b: 1227); Wagner et al. (2016: 44-53); UNHCR (2017). 
the details of the Dublin IV proposal, which has already been severely criticised by numerous observers? ${ }^{9}$. Rather, this article aims to develop a critical discussion of the relevant criteria for attributing competence to a single MS (not fundamentally questioned in the mentioned proposal) by adopting a conceptual framework in line with trends detectable in other significant areas in which a need to coordinate States' powers arises. It will emerge that, in order to be workable, any allocation system must satisfy several requirements: coherence with principles and values at stake; drafting of reasonable grounds for distributing competence; identification of the national authority which is best placed for managing a legal procedure (section II). The subsequent scrutiny of the present Dublin system will reveal its incapacity - as a whole - to cope with the relevant principles and values, retrieved in the primary rules governing EU asylum law and in international rules such as the Geneva Convention and the regime on the safety of life at sea (section III). A critical appraisal of the tool box at the disposal of the EU legislature when giving shape to a system of allocation is thereby proposed. An analysis is performed of the pros and cons of the main connecting criteria so far employed or proposed in the debate about the reform of the system (family ties, country of first entry, free choice). The discussion is then centred on the feasibility of an approach based on wider recourse to meaningful connections: substantial and procedural aspects will be covered, in the view that both are indispensable for a functioning system where the best placed authority is called to act. More importantly, it will be emphasised that it is time to break the taboo of quotas and that only a permanent mechanism for the fair sharing of applications can fully unfold the potentialities of newly drafted allocation criteria (section IV). Some tentative conclusions are proposed, highlighting that a discussion on the possible content of a different Dublin system is not just a theoretical speculation, but could provide a valid contribution to rebuild confidence in the ability of the EU to develop a credible and fair asylum area (section V).

In the course of the analysis, due account will be taken of the recent case law of the European Court of Justice (ECJ) and of the innovative position adopted by the European Parliament in the context of the legislative procedure concerning the Dublin IV proposal (the Wikström Report) ${ }^{10}$.

9 Among the first commentaries, see Capicchiano Young (2017); Chetail (2016a: 594598); Di Filippo (2016); Favilli (2017: 293-298); Hruschka (2016); Maiani (2016b); Morgese (2017); Vitiello (2016).

10 European Parliament, Committee on Civil Liberties, Justice and Home Affairs (Rapporteur Cecilia Wikström), "Report on the proposal for a regulation of the European Parliament and of the Council establishing the criteria and mechanisms for determining 


\section{THE DUBLIN SYSTEM AS A TOOL FOR COORDINATING STATES' COMPETENCE AND THE TRENDS EMERGING FROM OTHER FIELDS IN WHICH DELIMITATION OF STATE POWER IS DEALT WITH}

According to its Preamble, the declared purpose of the Dublin III Regulation $^{11}$ is to establish a "clear and workable method for determining the Member State responsible for the examination of an asylum application", a method "based on objective, fair criteria both for the Member States and for the persons concerned" and able to "determine rapidly the Member State responsible, so as to guarantee effective access to the procedures for granting international protection and not to compromise the objective of the rapid processing of applications for international protection".

To this author's knowledge ${ }^{12}$, no other precedent regarding the drafting of multilateral general and abstract rules for allocating competence in asylum procedures is detectable in international practice, while on a bilateral level the example of Canada/US cooperation may be quoted ${ }^{13}$.

Taking inspiration from the wording of the Preamble, the temptation is high to establish an analogy with the private international law terminology and to operate a sort of legal transliteration: The aim of the Dublin rules would be to prevent positive and (more commonly) negative conflicts of jurisdiction (meaning adjudicative power) over a peculiar personal status, by rapidly determining a single responsible Member State (MS). Nevertheless, caution is needed. The procedure for asserting the entitlement to international protection (to which the Dublin rules apply) is not usually framed as

the Member State responsible for examining an application for international protection lodged in one of the Member States by a third-country national or a stateless person (recast)", A8-0345/2017, 6-11-2017.

11 See recitals Nos. 4-5 of the Dublin III Regulation.

12 Some discussions were held in the Mercosur with the view of adopting an Agreement inspired by the Dublin II Regulation and by the then draft Council Directive on minimum standards on procedures for granting and withdrawing refugee status (later adopted as Directive 2005/85/EC, OJ L 326, of 13 December 2005, p. 13), following the presentation of a draft by Argentina in 2002: see Foro Especializado Migratorio del Mercosur, Anteproyecto de Acuerdo para la determinacion del responsable del examen de las solicitudes de refugio en el Mercosur, doc. MERCOSUR/RMI/FEM/ACTA No. 1/04, annex VII (14-16 April 2004). The discussions were later discontinued.

13 See the Agreement between the Government of Canada and the Government of the United States of America for cooperation in the examination of refugee status claims from nationals of third countries, done in Washington D.C. on 5 December 2002, entered into force on 29 December 2004 (the Canada/US Agreement). 
a typically judicial one, being rather peculiar and lying in a grey area between a classical administrative procedure and a quasi-judicial proceeding, according to the common law terminology ${ }^{14}$. It equally holds true that, as UNHCR (2011: $\$ 28$ ) aptly underlined, the status determination procedure has a declarative nature of the entitlement to precise subjective rights. From this perspective, it cannot be deemed so distant from certain non-contentious proceedings regarding personal or familiar statuses ${ }^{15}$, which in some States are entrusted to the judiciary whereas in others to specialised administrative authorities.

Here it is assumed that refugee status determination (RSD) procedures belong to the administrative competence of MSs and not to the judicial function proper: at the same time, this kind of administrative procedures bears some affinities with judicial activities (especially the non-contentious one), being both a manifestation of jurisdiction by the relevant State. When meant as determining the ability of States "to regulate or otherwise impact upon people, property and circumstances" — as Shaw (2008: 645) puts it — jurisdiction may take the form of legislative, executive or judicial action or competence $^{16}$. In the context of international cooperation, it is rare to find legal instruments addressing the allocation of executive competence, given that this topic is usually developed having in mind a strict correlation between territory and the activities of public authorities ${ }^{17}$. However, the EU legal order has developed some examples of allocation schemes in the executive realm, which may offer some interesting insights. Conversely, in the international

14 Actually, the solutions envisaged in the domestic legal orders vary considerably, so that the EU Qualification Directive clarifies that "determining authority" means any quasi-judicial or administrative body in a Member State responsible for examining applications for international protection competent to take decisions at first instance in such cases» (emphasis added): see art. 2 (f), Directive 2013/32/EU of the European Parliament and of the Council, of 26 June 2013, on common procedures for granting and withdrawing international protection (OJ L 180, of 29 June 2013, p. 60).

15 As merely illustrative examples: declaration of statelessness; rectification of civil status records; declaration of absence or of presumed death; approval of amicable separation of spouses; adoption of minors or of adults; recognition of motherhood or fatherhood.

16 The notion here discussed must be kept distinct from the meaning of the term jurisdiction as a threshold criterion to be satisfied in order for certain treaty obligations to arise: see, e.g., Milanovic (2011: 19-34), with a special focus on human rights treaties.

17 Rather, the questions more often raised in the practice are the recognition of foreign administrative acts and the definition of instruments of cooperation between national bodies, each one competent in its own territory: see, for instance, the classical work by Biscottini (1964). 
arena, it is rather common to encounter treaties or other binding instruments regulating the coordination of judicial competence in civil, commercial and criminal matters.

Against this background, in order to fuel the debate on a different way to conceive the Dublin system and to provide fresh arguments for the overhaul of the its current tenets, some inspiration may be drawn from the regimes developed in EU law, where the organisation of the competence of national administrative authorities has been addressed, and from the experience gained in the allocation of judicial competence, being that this form of public power insists on the efficient organization of legal procedures and has enjoyed more elaboration in international practice ${ }^{18}$.

As far as the administrative realm is concerned, a sector where the EU has elaborated guidelines on the allocation of competence to State authorities is competition law. In particular, following the entry into force of Regulation $1 / 2003$ on the implementation of the rules on competition laid down in arts. 101 and 102 TFEU $^{19}$, the role of domestic competition authorities sharply increased and, as a corollary, a need emerged to organise the distribution of tasks among them. In a joint statement annexed to the Regulation, the Council and the Commission acknowledged that cases "will be dealt with by a single competition authority as often as possible" and that, in order to designate the authority which is "well placed to act" (emphasis added) all relevant factors will be taken into account, and "in particular in which markets the main anti-competitive effects are felt and which authority is most able to deal with a case successfully depending on the ability of the authority to gather evidence, to bring the infringement to an end and to apply sanctions effectively" (emphasis added) ${ }^{20}$. In a related Notice drafted in close cooperation with Member States, the Commission provided

18 Far from establishing a simplistic equation between RSD procedures and contentious judicial proceedings, here it is simply suggested to bear in mind that the attribution of States' powers in the conduct of legal procedures raises common issues, regardless of the form of public function concerned and the subject involved (it is sufficient that it may pose issues of international interference or coordination in the States' action).

19 Regulation (EC) 1/2003 of the Council, of 16 December 2002, on the implementation of the rules on competition laid down in arts. 81 and 82 of the Treaty (OJ L 1, of 4 January 2003, p. 1).

20 Joint Statement of the Council and the Commission on the functioning of the network of competition authorities, 15435/02 ADD 1, 10-12-2002, \$\$ 15-16. It is also specified that a single national authority "will be usually well placed to act if only one Member State is substantially affected by an agreement or practice, particularly when the main anti-competitive effects appear in the same Member State and all participating 
additional clarifications as to those connecting criteria and meaningfully explained that those factors "indicate that a material link between the infringement and the territory of a Member State must exist in order for that Member State's competition authority to be considered well placed" (emphasis added $)^{21}$.

Another area of concern for the EU is short-term visas, regulated in the Community Visa Code ${ }^{22}$. When determining the MS competent to receive a visa application, art. 5 of the Visa Code logically follows a criterion inspired by a connecting factor approach, by stating that the MS competent to examine and decide on an application for a uniform visa shall be the MS whose territory constitutes the sole destination of the visit(s) or, if the visit includes more than one destination, the MS whose territory constitutes the main destination of the visit(s) in terms of the length or purpose of $s^{2} \mathrm{y}^{23}$.

The protective regime on the processing and the trans-border circulation of personal data is also illustrative. Under Directive $95 / 46^{24}$, a provision identifying the applicable national law is contained in art. 4 (1) (a), which states that "each Member State shall apply the national provisions it adopts pursuant to this Directive to the processing of personal data where: (a) the processing is carried out in the context of the activities of an establishment of the controller on the territory of the Member State". According to art. 28, the applicable law identifies the competent supervisory authority as well, although practical implementation may lead to the intervention of different national authorities ${ }^{25}$. What appears to be relevant here is that

companies to an agreement or an abusive behavior have their seat in that Member State".

21 Commission Notice on cooperation within the Network of Competition Authorities (OJ C 101, of 27 April 2004, p. 43), \$\$ 8-9.

22 Regulation (EC) 810/2009 of the European Parliament and of the Council, of 13 July 2009, establishing a Community Code on Visas (Visa Code) (OJ L 243, of 15 September 2009, p. 1).

23 See also the Commission Decision establishing the Handbook for the processing of visa applications and the modification of issued visas, C (2010) 1620 final, 19.3.2010, $\$ \$ 2.1-2.2$, where some concrete examples are given. Even this soft-law instrument was drafted in close cooperation with Member States.

24 Directive 95/46/EC of the European Parliament and of the Council, of 24 October 1995 , on the protection of individuals with regard to the processing of personal data and on the free movement of such data (OJ L 281, of 23 November 1995, p. 31).

25 See for the instance the questions decided by the Court of Justice in the judgement of 1 October 2015, Weltimmo, C-230/14, EU:C:2015:639. 
both the Preamble of the Directive $e^{26}$ and the ECJ case law ${ }^{27}$ underline the need to ascertain a substantial connection between the processing of personal data and a State territory in order to match the requirement of "activities carried out in the context of an establishment". The legislative framework is undergoing a significant change, as a new regulation repealing the directive, adopted in $2016^{28}$, will be applicable from 25 May 2018. Nevertheless, the elements relevant to determining the competent supervisory authority (or authorities) and the newly established notion of "lead supervisory authority" are again pervaded by a logic of assessing the substantive links between the activities at stake and the competent State $(s)^{29}$ and to single out the authority (or authorities) best placed to act.

What emerges from this merely illustrative list of regimes for distributing competence in the executive field looks to be in line with a general trend which may be observed in international law, where State powers are claimed or conferred in the presence of grounds which are deemed acceptable because of the existence of a reasonable connection between the acting State and the situation concerned. Which allocation criteria are acceptable and which are not must be addressed with regard to the kind of public power exerted (legislative, executive, judicial) and the specificity of the subject-matter, the values at stake and the general interests of the international community or sectors of the same ${ }^{30}$. An overview of the delimitation of the entire set of State competences would be impossible and certainly would exceed the purpose of this article. However, as already mentioned, the RSD procedure presents some affinities with judicial proceedings, at least for the circumstance that it deals with the impartial assessment of facts and circumstances in the context of a legal procedure and with the

26 See Recital 19, where it is specified that "establishment on the territory of a Member State implies the effective and real exercise of activity through stable arrangements", and that "the legal form of such an establishment, whether simply branch or a subsidiary with a legal personality, is not the determining factor in this respect".

27 See Weltimmo, \$\$ 28-39.

28 Regulation (EU) 2016/679 of the European Parliament and of the Council, of 27 April 2016, on the protection of natural persons with regard to the processing of personal data and on the free movement of such data, and repealing Directive 95/46/ EC (General Data Protection Regulation) (OJ L 119, of 4 May 2016, p. 1).

29 See for instance Recitals 36 and 124-128; arts. 4 (16) (22) and 55-56. See also art. 29 Data Protection Working Party, Guidelines for identifying a controller or processor's lead supervisory authority, adopted on 13 December 2016 and revised on 5 April 2017, 16/ EN WP 244 rev.01.

30 See inter alia Cassese (2001: 260-261); Mills (2014: 194-209); Oxman (2007); Vischer (2011). 
adoption of a decision having legal consequence on a personal status. If these assumptions may be deemed acceptable, then a look at the stance of the international community through some targeted references may prove interesting. Decades of international cooperation for the purpose of allocating judicial competence show that a primary consideration is given to the material connection of a situation or person with the State's legal order and community (as happens with legislative and executive jurisdiction too), and to the need to ensure an efficient and (possibly) speedy development of the legal procedure. The State best placed to properly hear a case and the country having an objective link with the situation, interests or legal rights at stake are usually considered entitled to assert exclusive, primary or (in some instances) concurrent adjudicative power ${ }^{31}$. An illustrative gallery of examples may be drawn from multilateral treaties adopted in distinct fora, widely ratified by the concerned States and addressing the fight against criminal activities ${ }^{32}$ or cooperation in civil ${ }^{33}$ or commercial ${ }^{34}$ matters, as well as from EU legislation in similar settings ${ }^{35}$.

31 See the authors quoted at footnote 30 and Von Mehren (2002: 27-73).

32 See inter alia the European Convention on Offences relating to Cultural Property, done in Delphi on 23 June 1985, art. 13; the United Nations Convention against Transnational Organized Crime, adopted by General Assembly resolution 55/25 of 15 November 2000, art. 15; the European Convention on Cybercrime, done in Budapest on 23 November 2001, art. 22; the United Nations Convention against Corruption, adopted by the General Assembly of the United Nations on 31 October 2003, art. 42.

33 See inter alia the Inter-American Convention on Support Obligations, adopted at Montevideo on 15 July 1989, art. 8; the European Convention on Civil Liability for Damage Resulting from Activities Dangerous to the Environment, done in Lugano on 21 June 1993, art. 19; the Unidroit Convention on Stolen or Illegally Exported Cultural Objects, done in Rome on 24 June 1995, art. 8; the Convention on Jurisdiction, Applicable Law, Recognition, Enforcement and Cooperation in Respect of Parental Responsibility and Measures for the Protection of Children, done at The Hague on 19 October 1996, arts. 5-14; the Convention on the International Protection of Adults, done at The Hague on 13 January 2000, arts. 5-12.

34 See inter alia the Convention on the Contract for the International Carriage of Goods by Road (CMR), done at Geneva on 19 May 1956, art. 31; the European Convention on Certain International Aspects of Bankruptcy, done in Istanbul on 5 June 1990, art. 4; the Mercosur Protocol on Jurisdiction in Contractual Matters, done in Buenos Aires on 5 August 1994.

35 The EU normative framework is particularly illustrative: see inter alia Regulation (EC) No. 2201/2003 of the Council, of 27 November 2003, concerning jurisdiction and the recognition and enforcement of judgments in matrimonial matters and the matters of parental responsibility (OJ L 338, of 23 December 2003, p. 1), arts. 
This brief excursus carried out in the administrative and in judicial contexts confirms the validity of the "connecting factors" idea and of the need to build around it a workable mechanism for identifying the State best placed to act.

Coming again to the asylum field, what must be now investigated are the grounds that may be deemed relevant and rational, considering the peculiarities of the subject matter and the principles and values at stake ${ }^{36}$. In order to do so, first, whether the Dublin III Regulation — as it stands - is able to comply with its wide-ranging guiding principles and other relevant international rules must be verified (section III). Second, an open-minded enquiry into the criteria so far employed is due, with a view to explain the current failures and propose a more robust recourse to meaningful criteria for singling out the most appropriate State authority (section IV).

\section{THE DEFICIENCIES OF THE DUBLIN SYSTEM IN ITS BROADER LEGAL CONTEXT}

This section discusses the current performance of the Dublin system as an allocative mechanism is carried out. As yardsticks of reference the guiding principles of the CEAS (as enriched by the Lisbon Treaty) will be primarily taken into account. However, the interaction with other legal regimes grounded in international law and relevant for this field will also be examined

3-20; Directive 2011/93/EU of the European Parliament and of the Council, of 13 December 2011, on combating the sexual abuse and sexual exploitation of children and child pornography (OJ L 335, of 17 December 2011, p. 1), art. 17; Regulation (EU) No. 650/2012 of the European Parliament and of the Council, of 4 July 2012, on jurisdiction, applicable law, recognition and enforcement of decisions and acceptance and enforcement of authentic instruments in matters of succession and on the creation of a European Certificate of Succession (OJ L 201, of 27 July 2012, p. 107), arts. 4-19; Regulation (EU) No. 1215/2012 of the European Parliament and of the Council, of 12 December 2012, on jurisdiction and the recognition and enforcement of judgments in civil and commercial matters (OJ L 351, of 20 December 2012, p. 1), arts. 4-35; Directive (EU) 2017/541 of the European Parliament and of the Council, of 15 March 2017, on combating terrorism (OJ L 88, of 31 March 2017, p. 6), art. 19.

36 This also explains why the connecting factor idea, albeit common to various legal fields (as outlined above), requires a distinct analysis for each relevant area, and it is not fruitful to insist too much on a detailed comparison of the various ways in which it is declined. A different stance would lead to a merely descriptive approach. 
in order to offer a complete picture of the inadequacy of the rule currently in force and of the strong exigency of a substantial change.

\section{THE GUIDING PRINCIPLES OF THE CEAS AND THE INABILITY OF THE DUBLIN SYSTEM TO COMPLY WITH THEM}

When critically discussing the Dublin system, it is necessary to place it in the broader context of the CEAS, taking into due account the evolution that the Treaties underwent after the entry into force of the Treaty of Lisbon. It is of pivotal importance to remember that the Dublin Regulation (the current one, or a future one) is not a self-contained regime. Likewise, it must not be treated as a taboo, impermeable to discussions on its past and current contents.

As a first step in this analysis, it should be kept in mind that the guiding principles (or foundations) of the CEAS are, according to art. 78 (1) TFEU: offering appropriate status to any third-country national requiring international protection; ensuring compliance with the principle of non-refoulement (in the version enshrined in art. 19 EU Charter of Fundamental Rights, EUCFR); fully respecting the 1951 Geneva Convention and its 1967 Protocol relating to the status of refugees, and other relevant treaties. More broadly, the EU Charter (and in particular, its art. $18^{37}$ ) must be taken into account when designing and interpreting EU rules on asylum.

Furthermore, according to art. 80 TFEU, the EU asylum policy must be governed by the principle of solidarity and fair sharing of responsibility, including (but not limited to) its financial implications, between the Member States. The aforementioned provision underlines that, whenever necessary, the Union acts adopted in this field must contain appropriate measures to give effect to this principle. If it is true that the mentioned principle is not a directly enforceable one and requires the exercise of legislative and political discretion for its implementation ${ }^{38}$, it is worth stressing that the need to conciliate EU acts with art. 80 TFEU cannot be confined to ad hoc emergency measures, but must also encompass general and abstract provisions. In fact, nothing in the wording and in the spirit of art. 80 TFEU precludes its scope from em-

37 "The right to asylum shall be guaranteed with due respect for the rules of the Geneva Convention of 28 July 1951 and the Protocol of 31 January 1967 relating to the status of refugees and in accordance with the Treaty on European Union and the Treaty on the Functioning of the European Union".

38 On art. 80, see inter alia Gestri (2011); Morgese (2014); Vanheule et al. (2011). 
bracing the same drafting of general rules ${ }^{39}$ : They may have a financial character, or concern operational support, or even frame the general features of the CEAS, such as the criteria assigning responsibility to individual Member States (i.e. the current Dublin III Regulation). This holds true, in particular, when it is proven beyond any reasonable doubt that those provisions, already in force, cause unfair and inefficient results. The fact that the Dublin system was not originally conceived as a responsibility or burden sharing mechanism cannot be a justification for the maintenance of its main tenets after the entry into force of the Lisbon Treaty and in light of its repeatedly tested (bad) performance: art. $80 \mathrm{TFEU}$ is a binding principle for the EU legislature, and this applies in the context of the drafting of both general rules and emergency driven measures.

In its recent judgement on the relocation litigation, the Grand Chamber of the Court of Justice did not miss the occasion to solemnly recall that the principle of solidarity and fair sharing of responsibility between the Member States "governs EU asylum policy" and that it "applies, under Article 80 TFEU, when the EU common policy on asylum is implemented" 40 . Additionally, even art. 67 (2) TFEU (stating that the Union "shall frame a common policy on asylum, immigration and external border control, based on solidarity between Member States, which is fair towards third-country nationals", emphasis added) proves relevant by underlining the need not to omit the consequences within the personal sphere of the asylum seekers.

It is no surprise that the same Dublin III Regulation ${ }^{41}$ identifies that a primary goal of this set of rules is to rapidly determine the MS responsible and to put it in the best situation to carry out the refugee settlement procedure (RSD), employing criteria that are fair both for the MSs and the applicants (emphasis added). This represents another yardstick against which to measure the soundness of the current legislative framework. Considering that the effect of the Dublin regulation is to affirm a strict system of coordination of exclusive competence (and not alternative or concurrent, for the disposal of the applicants),

39 For a similar view, see Basilien-Gainche (2011: 251-253); De Bruycker \& Tsourdi (2016a: 512); Di Filippo (2017: 451-452); Garlick (2016: 167-168); Gestri (2011: 904-905); Gray (2013: 179-180, 191-192); Karageorgiou (2016: 6-7); Kuçuk (2016: 448, 458-461); Moreno-Lax (2017: 751-754); Morgese (2014: 474-476); Tsourdi (2017: 672-675).

40 Judgement 6 September 2017, Slovak Republic and Hungary v Council of the European Union, joined cases C-643/15 and C-647/15, EU:C:2017:631, $\$ 252$ and $\$$ 291.

41 See recitals 4-5. 
it is even more crucial to verify whether the choice of the competent State is driven by rationality and fairness.

This being said, more than twenty years of implementation of the Dublin system have shown that, as currently framed, it simply does not work, either in "calm" periods or in times of "crisis" are concerned, they do not really cooperate and do not fully respect their obligations, appearing more interested in shifting responsibilities as much as they can. The Dublin procedures are very slow and often end up dans une impasse. The frontline States may suffer a disproportionate burden as a consequence of the criteria set out in the relevant provisions. The presumption of the equivalence of the national asylum systems - upon which the Dublin rules are based - is flawed, and the applicants know this perfectly. As a consequence, some second line countries, which have more efficient and/or generous asylum systems or better socioeconomic conditions, become the favourite destinations in secondary movements, fueling social tension and provoking additional pressure on national budgets.

Furthermore, a careful assessment of the material dynamics of the applicants provides additional indications. The fact that no reasonable room is given to a consideration of asylum seekers' preferences or their prospects for integration creates a trend against spontaneous compliance and towards secondary movements. Focusing instead on the (prospectively) recognised holder of international protection, he/she will have to face a long-term process of integration in the hosting State, which may prove to be extremely complicated when there are not substantial links with the local environment. This might have a high financial impact on the host State (costs for language courses, assisting the protected persons in integrating and finding a job, countering probable social exclusion, etc.) and also negatively reflect on the capacity of the protected person to reach independence from State aid in a short time, to stimulate self-empowerment, and to positively contribute to the cultural and social development of the country concerned. A frustrated, poorly integrated and under-employed refugee is a problem not only for the person involved, but also for the host community: Such a situation is a lose-lose one, both for the refugee and the host $S_{t a t e}{ }^{43}$.

The poor performance of the Dublin system generates high costs of different natures, such as: (a) the waste of public money in repressive actions and in administrative procedures which are slow and do not produce durable

42 For all relevant references, see Maiani (2016b: 12-27); Wagner et al. (2016: 44-53).

43 On these aspects, see inter alia Byrne \& Shacknove (1996: 205-207); Noll (2002: 313, 319-321). 
results ${ }^{44}$; (b) diplomatic tensions between the Member States and excessive burdens for some of them, sometimes leading to the collapse of the national asylum system, wave-through policies and the reinstatement of checks at internal borders (to the detriment of the whole Schengen area); (c) profit making for criminal networks providing smuggling services; (d) social exclusion and frustration for asylum-seekers; (e) the lack of integration for recognised refugees, with increased costs for social services and public expenditures.

To sum up, the current rules and their usual implementation do not offer any guarantee that quick access to an asylum procedure will be granted, that responsibility will be assigned in a fair and efficient manner, that appropriate status will be afforded to the beneficiaries of international protection, or that the principle of fair sharing of responsibilities and solidarity among the MSs will truly be implemented. All this is already sufficient to justify a radical overhaul of the Dublin machinery in force. But additional arguments may be drawn from the relevant international provisions, some of which are explicitly named in art. 78 TFEU.

\section{THE UNDERLYING TENSION WITH THE GENEVA CONVENTION}

Considering that all the MSs are bound by the Geneva Convention and that the same art. 78 TFEU subordinates the CEAS to the full respect of that treaty, is the Dublin system coherent with international refugee law when it states that the applicant may ask for protection in only one MS, which is not necessarily the one chosen by him/her? At a first glance, the Convention does not deal with the issue of the distribution of responsibilities among the contracting parties. Its main purpose is to establish a set of obligations binding any contracting State under whose jurisdiction an asylum claim is presented (regardless of how the person actually arrived), and a correspondent set of rights afforded to the applicant and (mainly) to the prospective refugee.

The fact that a contracting State refuses to grant protection and transfers the responsibility (and the applicant) to another State requires a careful examination because this might imply an evasion of the relevant treaty obligations. As a matter of international law, it has been noted that the Convention implicitly recognises a right to choose the State to lodge an application among

44 This waste of money concerns the Member States' budgets, but has negative effects even on EU expenditures. In fact, the European funds given to the Member States to manage the processing of asylum claims and the subsequent integration of the persons entitled to international protection may prove ineffective. The same goes for the funds devoted to facing emergencies caused by extraordinary flows. 
the contracting parties, not obliging the concerned person to seek asylum only in the first safe country encountered during his/her flight ${ }^{45}$. According to the prevailing view, however, international practice shows that this implicit freedom should be weighed against the faculty for the State concerned to transfer the responsibility to a safe third country willing to accept it and respecting the Convention (including not only the non-refoulement guarantee, but even the substantive rights enshrined in its provisions) and basic human rights ${ }^{46}$. In this respect, it does not seem that art. 18 of the EUCFR has fundamentally altered the framework, although it is certain that it gives prominence to the position of the individual and, according to several scholars ${ }^{47}$, affords a subjective right to be granted asylum once it is verified that the conditions laid down in the Geneva Convention and in the Qualification Directive ${ }^{48}$ have been met. It is not possible to explore this issue more thoroughly here, but it must be recognised that the safe third country concept is challenging ${ }^{49}$ and that it has developed into various devices, all of which share the fact that the will of the asylum seeker does not play a determinant role: The EU itself codified this in the Dublin system (regarding infra-regional allocation) ${ }^{50}$ and

45 See among others Cannizzaro (2011: 442-443); Durieux (2009: 78-79); Gaja (2014: 139-142, 144); Gil-Bazo (2007: 176-180); Goodwin-Gill \& McAdam (2007: 392 396); Hathaway (2011: 3-4); Moreno-Lax (2015: 691-695). Contra, see Hailbronner (1993: 58, 61-64); Lambert (1995: 91-98).

46 See inter alia Byrne and Shacknove (1996: 214 et seq.); Goodwin-Gill \& McAdam (2007: 392-396); Hathaway (2011: 3-4). See also UNHCR (1994), UN General Assembly, "New York Declaration for Refugees and Migrants", A/RES/71/1, 19.9.2016 (hereinafter, 'the New York Declaration'), $\$ 70$.

47 See Bodart (2018); Carlier (2002: 185-186); Den Heijer (2014); Gil-Bazo (2008); Gortázar Rotaeche (2009: 624-627).

It is worth underlining that those opinions refer to situations in which the competent MS (according to the Dublin rules) has already been determined, and not to the issue of the right to choose that State.

48 Directive 2011/95/EU of the European Parliament and of the Council, of 13 December 2011, on standards for the qualification of third-country nationals or stateless persons as beneficiaries of international protection, for a uniform status for refugees or for persons eligible for subsidiary protection, and for the content of the protection granted (OJ L 337, of 20 December 2011, p. 9).

49 Amongst the recent contributions, see the extensive and detailed essay of Moreno-Lax (2015: 695-705, with further references).

50 Recently, the Court of Justice confirmed such view: judgement 6 September 2017 (Grand Chamber), Slovakia and Hungary v. Council of the European Union, joined cases C-643/15 and C-647/15, EU:C:2017:631, \$\$ 338-342. 
in the Procedures Directive (with regard to non-EU countries) ${ }^{51}$. At the same time, it is true that (as art. 78 TFEU clearly spells out) legal instruments such as the Dublin III Regulation are subordinated to the Geneva Convention, and that - if art. 18 of the Charter must be taken seriously - the position of the individual cannot be reduced to a mere object in the legal framework.

Leaving aside the issue of the safe third country concept as regulated in the view of transferring responsibility to non-EU countries and focusing here only on the Dublin system, it seems sound to state that whereas the allocation of jurisdiction reduces the scope for the self-determination of the applicant and objectively disposes of his or her "fate", great care must be given to the actual level and quality of the asylum system of the designated MS, as a formal respect for the Convention or the sole implementation of the non-refoulement guarantee are not sufficient. Not by chance, art. 78 TFEU speaks of a "full implementation" of the Convention, and words do bear legal consequences. On this point, notwithstanding the parallel harmonisation of substantive and procedural issues ${ }^{52}$, a certain tension is still present, and it cannot be simply removed by the ECJ case law ${ }^{53}$. In my opinion, this would justify the search

51 Directive 2013/32 of the European Parliament and of the Council, of 26 June 2013, on common procedures for granting and withdrawing international protection (recast) (OJ L 180, of 29 June 2013, p. 60).

52 The Dublin Convention and the Dublin II Regulation were disappointing regarding this aspect, as they did not take into account the possibility that the competent MS would not offer a guarantee of actual respect for the Geneva Convention, basic human standards and the relevant EU rules on reception, procedures, qualification and treatment: see, for instance, the critical remarks advanced by Guild (1999: 320-321); Hathaway (2011: 1-4, 7).

53 The European Court of Justice started addressing this issue in its landmark judgement of 21 December 2011, N. S. and Others, C-411/10 and C-493/10, EU:C:2011:865, inspired by the case law of the European Court on Human Rights (see especially judgement 21 January 2011, M.S.S. v. Belgium and Greece, no. 30696/09, CE:ECHR:2011:0121JUD003069609).

The Dublin III Regulation partly remedied the mentioned gap by introducing the current art. 3 (2), which, however, leaves room for transfers where an individual risk of violation of essential rights is not due to "systematic flaws" in the asylum procedure and in the reception conditions for applicants: for a similar criticism, see inter alia $\mathrm{Fe}-$ raci (2013: 25); Chetail (2016b: 34-35); Maiani (2016a: 133-138); Vedsted-Hansen (2016: 338-352).

Recently, the ECJ paved the way for a more balanced harmonisation between human rights standards and the implementation of the Dublin III Regulation: see Judgement 16 February 2017 (Chamber), C. K., H. F., A. S. v Republika Slovenija, C-578/16 
for different solutions, striking a new balance between the States' discretion and the applicant's perspective, as already noted by Gaja (2014: 144-145).

Another argument about the opportunity to seriously reconceive Dublin may be drawn from the somewhat puzzling relationship between the rationale of the criteria of first entry therein specified and the full implementation of the non-refoulement guarantee enshrined in art. 33 of the Geneva Convention and later guaranteed in other international instruments (last but not least, art. 19 of the EUCFR), as will be detailed below (section IV.2.1).

Finally, the preamble of the Geneva Convention contains a policy formula which is too often neglected. The Parties expressly recognise that "the grant of asylum may place unduly heavy burdens on certain countries, and that a satisfactory solution of a problem of which the United Nations has recognized the international scope and nature cannot therefore be achieved without international co-operation". The evaluation of fairness/unfairness at the global level has always proven challenging. Nevertheless, international cooperation at a regional level, if carried out, should aim at relieving the overburdened States (both the first line and second line ones) of part of the responsibility, and not at aggravating their duties. Since the Dublin system is a form of concerted management of refugee claims, it can be matched against this policy principle. However, the outcome cannot be satisfactory due to the reasons mentioned in section III.1.

\section{THE SIDE EFFECTS ON THE SEARCH-AND-RESCUE REGIME AT SEA}

A final (but equally worrying) side effect of the Dublin system concerns the adherence to the rule on the safeguarding of life at sea in the context of mixed flows affecting the EU Member States ${ }^{54}$. Due to geographical and logistic reasons, or to the "closure" of certain terrestrial routes and of the totality of the air routes, the vast majority of irregular arrivals of asylum seekers occur through the maritime route. In the recent past, the conduct of search and rescue (SAR) operations has been conditioned in a negative way by the current state of affairs, whereas the EU country accepting disembarkation is usually bound to assume responsibility for the asylum seekers under the

PPU, EU:C:2017:127, \$\$ 90-94; Judgement 26 July 2017 (Grand Chamber), Jafari, C-646/16, EU:C:2017:586, \$ 101.

54 On this challenging subject, see inter alia Acosta Sánchez (2017); Di Filippo (2014b); Marinai (2016); Moreno-Lax and Papastavridis (2016); Parisciani (2015). 
Dublin rules ${ }^{55}$ and to manage the presence of other migrants with an irregular status as far as entry and stay are concerned. A situation is created in which the EU coastal State willing to facilitate SAR operations or to strengthen its rescuing capacities - thus contributing to an enhanced enforcement of international maritime law — will be rewarded by the additional burden of assuming responsibility for asylum seekers and other migrants under the applicable EU provisions. This might explain why, on some occasions, certain coastal States have refused or delayed disembarkation from rescuing ships (regardless of whether they are private or public vessels), or why commercial ships being aware of the risk of being caught in a diplomatic disagreement among the relevant coastal States - preferred to refrain from intervening in order to save time and money.

At the same time, the aforementioned reward argument helps us to understand why multilateral naval missions in the Mediterranean Sea suffer from relatively little participation by non-Mediterranean States; even when the naval assets are deployed, this is regularly made conditional upon the acceptance of a rule of engagement providing for the disembarkation of the rescued people in the coastal country which is entrusted with the general coordination function of the mission or closer to the SAR event ${ }^{56}$. It is not by coincidence that, in order to avoid disincentives for the State accepting disembarkation or for the (prospective) rescuing ships, the UNHCR has underlined on several

55 To this author's knowledge, no Southern EU MS has officially questioned the applicability of the criterion of first entry to asylum seekers disembarked after a SAR operation, although the issue of the unfair effects of such interpretation is increasingly being raised at the political level, especially in the context of the drafting or adjourning of the operational plan of joint missions such as Triton, Sophia or Themis: for some references, see Caffio (2018); The New York Times (2018). In new EU sea mission, ships not obliged to bring migrants to Italy, The New York Times, 1-2-2018.

At the EU level, some doubts were raised by Advocate General Sharpston in the Opinion delivered on 20 June 2017 in the case Mengesteab, C-670/16, EU:C:2017:480, $\$ \$ 44-57$. In addition, drawing inspiration from the Opinion issued by Sharpston on 8 June 2017 (EU:C:2017:443) in the cases C-490/16 (A.S. v Republic of Slovenia) and C-646/16 (Jafari), the applicability of art. 13 Dublin III Regulation might be questioned at least in the event of a massive inflow of people by sea (see especially $\$$ 189 of the Opinion). However, the Court, in the two judgements delivered on 26 July 2017 (EU:C:2017:585 and EU:C:2017:586), held a different vision on this point: see infra, section IV.2.2.

56 See the operative plan of the joint missions Triton and EUNAVFOR MED Sophia. For further references, see, for instance, Marinai (2016: 924-926); Parisciani (2015: 166-168). 
occasions that new solutions must be envisaged by pointing at delinking, in some instances, the acceptation of disembarkation and the assumption of responsibility for the rescued persons ${ }^{57}$.

In conclusion, it may be inferred that the Dublin scheme produces punitive effects on Member States that are genuinely committed to respecting the SAR obligations under international maritime law. A tension with the latter duties can thus arise, but it is not unavoidable: It is sufficient to seriously discuss the tenets of the EU regime of responsibility allocation.

\section{THE WAY FORWARD: THE NEED TO RECONSIDER ALLOCATION CRITERIA ON A PRINCIPLED BASIS}

In sum, the Dublin system produces results which are far from coherent with the guiding principles of the CEAS (as enshrined in arts. 76, 78 and 80 TFEU and in the EUCFR) and with the objectives of the same Dublin III Regulation; moreover, it may determine outcomes which are inconsistent with other relevant international rules and principles. If viewed through the lens of the international lawyer and according to the trends detected above (section II), it does not set up a credible and workable definition of the rules for identifying the most convenient or appropriate forum for conducting the RSD procedure. When the outcome of a certain approach is flawed, no rational lawmaker should insist on $\mathrm{it}^{58}$. Again, the history of the evolution of the jurisdictional grounds in civil and criminal matters ${ }^{59}$ is revealing.

As aptly put by Maiani (2016a: 102), the current regulation is just "one of several systems of responsibility-allocation that could theoretically be adopted under the EU Treaties". It is thus of paramount importance to critically discuss at some length the main criteria so far employed in the Dublin system or proposed in the debate surrounding its reform and to explore the soundness of the possible alternatives. In doing so, the values at stake and the interests of the concerned parties will be taken into due account, as well as the fact that a perfect criterion simply does not exist. The real challenge is to single out the ones which are intrinsically sounder - according to constitutional principles and the exigency of rationality when managing a complex legal procedure

57 See, for instance, UNHCR (2011: 8, 12); UNHCR (2017: 3-4). See also Klug (2014: 60-61). For some concrete proposals, see Di Filippo (2014a); UNHCR (2015: 2-4).

58

See, for instance, Lagarde (1986: 194); Fernández Arroyo (2006: 247).

59 See Lagarde (1986: 194); Mills (2014: 230-235); Shaw (2001: 652-687). 
— and to develop a workable framework around them which includes a full implementation of art. $80 \mathrm{TFEU}$, innovative tools and fast track procedures.

\section{FAMILY RELATIONS AND THEIR ENHANCED ROLE IN A DISPLACEMENT SETTING}

While family unity, as a connecting factor, is traditionally put into relation with the human right to enjoy a family life (as enshrined in international provisions such as art. 8 ECHR or art. 7 EUCFR) and with the best interests of the child under the 1989 UN Convention on the Rights of the Child, in this context, it is stressed that a correct assessment of its relevance is coherent even with the public interests of the Member States and of the EU.

This ground for allocating competence has undergone a significant evolution under the various stages of the Dublin legal framework. In particular, the Dublin III Regulation ${ }^{60}$ expanded the relevance of the family link compared to the Convention ${ }^{61}$ and to the Dublin II Regulation ${ }^{62}$. In the proposal for a Dublin IV Regulation, the Commission envisages broadening the scope of family members to include siblings in any circumstance ${ }^{63}$, and this is a positive step. Nevertheless, this is not enough.

An expansive notion of family would be preferable, and in particular the presence of relatives in a Member State deserves more careful consideration. In contrast to some European countries, in many countries of origin, relatives are as important in family life as the core family members, due to the cultural concept of family and the related moral obligations of mutual assistance and care. Moreover, on occasions when the original nuclear family may be dispersed or deceased, the only form of family life available to the asylum seeker may be represented by a cousin, an aunt or an uncle, a nephew or a grandparent. Finally, many asylum seekers have suffered a traumatic experience in their country of origin and/or during their journey to Europe, so that the closeness to persons coming from the same familiar milieu — regardless of how old the individuals at stake are - may prove to be fundamental for their psychological welfare and propensity to establish a collaborative and fruitful relationship with the local officers managing the asylum procedure and with the surrounding social environment.

60 See art. $2(\mathrm{~g})$ and arts. 8-10.

61 See art. 4 of the Convention.

62 See arts. 6-8 Regulation No. 343/2003.

63 See art. 2 (g) of the draft text. 
In sum, a wide sample of family members (expanded to relatives) should serve as a connecting factor for any asylum seeker (and not only for unaccompanied minors) and would result in attributing competence to the State concerned $^{64}$. Some adjustment might be framed (for instance, a hierarchy between core family members and relatives) and a requisite of proof of the capacity to take care of the asylum seeker might be introduced (especially for relatives). The time has come to look at (wider) family links as relevant connecting factors, to the benefit of the asylum seeker and the host State and the European Union as a whole. It is not casual that in the different (but not wholly unconnected) field of the provision of legal channels to get to Europe, two Member States have already accepted the involvement of relatives of asylum seekers in humanitarian admission schemes ${ }^{65}$. In the end, forced displacement obliges persons to build a new life: Who would not seek the support of his/her family environment in such a problematic endeavour?

\section{THE "AUTHORISATION PRINCIPLE" AND THE COUNTRY OF FIRST IRREGULAR ENTRY}

When criteria inspired by family ties are not applicable, the Dublin Convention and the ensuing Regulations have applied, in succession, several connecting factors inspired by the so-called "authorisation principle", i. e. the assignment of responsibility to the State that played the most important part in the entry or residence of the person concerned: the State that issued a valid residence permit or visa (art. 12); or the State whose borders have been regularly (art. 14) or irregularly (art. 13) crossed by the asylum seeker. A residual criterion is represented by the State where the application is lodged (art. 15 regarding international transit zones in airports; art. 3 (2) as a final default heading).

\subsection{A connecting factor whose rationale is far from rational}

The implementing practice shows that the irregular entry criterion is the most commonly used ${ }^{66}$. What is the rationale behind this connecting factor?

64 A more liberal view has actually been employed in a similar instrument, i.e. the Canada/US Agreement. Under art. 1 (1), "Family Member means the spouse, sons, daughters, parents, legal guardians, siblings, grandparents, grandchildren, aunts, uncles, nieces, and nephews".

65 See the examples of Germany and Ireland reported in European Union Fundamental Rights Agency (2015: 6, 9).

66 See supra, footnote 7. 
Commentators agree on the fact that the drafters of the Dublin Convention and of the subsequent Dublin II and III Regulations intended to establish a linkage between the allocation of responsibility in the field of asylum and the respect for the MS' obligations in the protection of the EU external border ${ }^{67}$. Put in another way, if a Member State does not reject an asylum seeker at its border, and lets him/her enter its territory, then it would be logical (sic) to establish the responsibility for assessing the asylum claim there, and if the outcome is positive, to define that MS as the new place of residence for the beneficiary of international protection. Nevertheless, the principle of non-refoulement is applicable on entry regardless of the efficiency of the checks at the external borders: A State managing an external border control cannot decide to authorise or not the irregular entry of an asylum seeker, but is obliged to grant access to an asylum procedure to anyone who lodges an application. And as everyone knows - the combined effect of the current EU visa policy, the $\mathrm{EU} /$ national carrier sanctions regimes, the smugglers' tactics and the nature of the flows to Europe unavoidably causes an excessive burden for a few frontline States. As has been aptly underlined by Hruschka and Maiani (2016: 1524), this criterion "ends up encouraging lax borders controls or - worse — illegal pushbacks and other such practices" 68 . Additionally, asylum seekers cannot benefit from the occurrence of meaningful links with other MSs, thus generating the negative consequences mentioned above including secondary movements (supra, section III.1). All this is hardly coherent with the principles embodied in art. 78 TFEU and in arts. 18-19 EUCFR.

What is not often underlined is that the number and identity of the frontline States may change over the course of time. Thus, in the first years of the implementation of the Dublin Convention, Germany was situated at the external border of the Schengen area and was concerned by consistent irregular flows coming from or through the Visegrad countries and from the Balkans. Later, the land border of the Schengen area shifted eastbound and southbound, so that currently, other MSs may face the effects of the first country of entry criterion. It is sufficient to consider the events that occurred in 2015-2016, which led to the pronouncement of the Court of Justice in

67 See, for instance, Hruschka and Maiani (2016: 1523); Hurwitz (1999: 648, 657). This rationale is confirmed by the Commission's Communication, "Towards a Reform of the Common European Asylum System and Enhancing Legal Avenues to Europe”, COM (2016) 196 final, 6-4-2016, p. 7.

68 From the same perspective, see Morgades-Gil (2017); Thym (2016: 1550). For a critical assessment of Hungary's policy in response to the 2015-2016 events, see Fernández Arribas et al. (2016). For a worrying account on the trends emerging in several Member States, see European Union Agency for Fundamental Rights (2018), pp. 2-7. 
Jafari: Considering that the Greek asylum system was still unable to fulfill its normal functions, the next responsible countries for the vast majority of the people fleeing the Syrian conflict and other unsafe countries of origin were Hungary or Croatia, according to the itinerary followed by the concerned persons. As aptly underlined by Advocate General Sharpston in her Opinion in Jafari, such situation was unbearable for any national system, whether it was the Croatian one or any other ${ }^{69}$. This has been confirmed by the fact that the Dublin rules have been in part ignored (by transit countries, adopting a wave-through policy) and in part suspended thanks to the temporary availability shown by Germany to host asylum seekers coming from Syria ${ }^{70}$. However, after a few months, the German government felt compelled to revoke its openness policy, and later, Sweden and Austria reached a saturation point and asked the Council for a partial derogation ${ }^{71}$ of the implementation of the relocation scheme approved a few months before to the benefit of Greece and Italy $^{72}$. In Spring 2016, a series of initiatives - partly elaborated and implemented outside of the EU legal order - led to the "closure" of the Balkans route and to the adoption of the debated EU-Turkey Statement of 18 March 2016. A sort of normality was restored, but this was certainly not thanks to the Dublin rules. It might be argued that the 2015-2016 situation along the Balkans was exceptional and that the Dublin criteria usually work. But this is not the case, as abundantly revealed by the consistency of the literature, as mentioned above ${ }^{73}$.

Thus, the abovementioned rationale is at odds with the basic principles of refugee law mentioned in art. 78 TFEU (and in the EUCFR) and produces an unbalanced distribution of responsibilities, contrary to the principle of solidarity and fair sharing among the Member States reflected in art. 80 TFEU.

69 Opinion of 8 June 2017, EU:C:2017:443, \$\$ 228-238.

70 This unilateral decision grosso modo recalled the so-called sovereignty clause enshrined in art. 17 (1) Dublin III Regulation: see Kalkmann (2015: 24); Maurice, E. (2015). Germany makes U-turn on Syria refugees. EUobserver, 11-11-2015. Available at: https://euobserver.com/migration/131062.

71 See Implementing Decision (EU) 2016/408 of the Council, of 10 March 2016, on the temporary suspension of the relocation of $30 \%$ of applicants allocated to Austria under Decision 2015/1523 (OJ L 74, of 19 March 2016, p. 36); Decision (EU) 2016/946 of the Council, of 9 June 2016, establishing provisional measures in the area of international protection for the benefit of Sweden in accordance with art. 9 of Decision 2015/1523 and art. 9 of Decision 2015/1601 (OJ L 157, of 5 June 2016, p. 23).

72 See the account given in the Sharpston's Opinion, EU:C:2017:443, \$\$ 5-18.

73 See supra, footnotes 3 and 7. 
Since the entry into force of the Lisbon Treaty, this criterion and its confirmation in the Dublin III Regulation no longer have a reasonable justification. Additionally, it must be pointed out that the criterion here criticised is applied even to persons rescued at sea and to the State accepting disembarkation. This provokes a relevant tension over the system of search-and-rescue at sea, as already outlined ${ }^{74}$.

An objective evaluation of this criterion, embracing both its purported rationale and its practical effects, should lead to a search for alternatives.

\subsection{The signals coming from the Court of Justice: a sober push for a change}

The discomfort with this method for allocating competence led Advocate General Sharpston to propose an interpretative approach, sensitive to arts. 78 and 80 TFEU, according to which art. 13 Dublin III Regulation would not apply where a sudden massive inflow of third country nationals occurs since it was not conceived for addressing such scenario ${ }^{75}$. In the view of the Advocate General, insisting on that criterion would run contrary to the purported objective of the Dublin III Regulation to found the allocation of competence on fair criteria, both for the Member States and the persons concerned $^{76}$. In the described scenario, the default criterion of art. 3 (2) would apply, i.e. the first Member State in which the application for international protection was lodged shall be responsible for examining it. The reading of art. 13 advanced by Sharpston - though intriguing — would end up in an indirect modification of the Regulation, rendering a free choice approach as the determining key for allocating competence ${ }^{77}$, albeit only in exceptional circumstances.

I fully share the criticism of the first country of entry criterion, but respectfully deem that such interpretation of art. 13 raises several concerns. First, it causes uncertainty about when the threshold of "sudden massive inflow" is triggered. Second, it is doubtful that the legislature, when adopting the Dublin III Regulation, did not take into account the eventuality of sudden massive inflows, causing a serious disturbance to the ordinary functioning of the responsible MS: The real trouble lies, instead, in the very fact that the Council and Parliament were aware of such scenario in 2013 and decided to

\footnotetext{
74 See above, section III.3.

75 See Sharpston's Opinion, EU:C:2017:443, \$\$ 178-189.

76 See recital 5 of the Dublin III Regulation.

77 Presumably, any applicant would lodge his/her claim in the preferred country of final destination.
} 
be satisfied by some remedial and ex post measures which are totally insufficient (see below). Third, if in the case of massive inflows, the frontline country is authorised to disregard the protection needs of asylum seekers and to let them pass through, so that they can lodge their requests for international protection in a subsequent Member State of their choice, what then occurs runs equally counter to the principle of solidarity and fair sharing among the Member States. Moreover, it creates an evident disturbance to the public order of the interested countries and increases the risks of violations of the human rights of the persons on the move, especially the most vulnerable ones. I will return to this issue in section IV.3.

It must be recalled here that, if the AG has been perhaps too provocative in her reading of art. 13, on the contrary, the Court of Justice adopted an apparently conservative stance ${ }^{78}$. In a rather laconic fashion, the judges take note of (and fully endorse) the linkage established by the Dublin III Regulation between the competence for an asylum application and the role played by a MS with regard to the entry into the EU of a third country national, even in the case when this happened according to a decision of a humanitarian nature $^{79}$. The dubious rationale of this legislative choice is not even indirectly questioned, and a disturbing conception of Dublin as a sort of self-contained regime - impermeable by an evaluation under arts. 78 (1) and 80 TFEU transpires in some passages ${ }^{80}$.

Another finding of the Court may be questioned, i.e. its statement that in responding in an appropriate way to situations of massive inflows, several instruments are at the disposal of the EU and the $\mathrm{MSs}^{81}$. Such tools are the mechanisms regulated in art. 33 Dublin III Regulation ${ }^{82}$, Directive 2001/55 on temporary protection ${ }^{83}$, the $a d$ hoc measures which may be adopted under art. 78 (3) TFEU (such as the decisions on a temporary scheme for relocation for the benefit of Greece and Italy), and the unilateral recourse by the other MSs to the sovereignty clause under art. 17 (1) Dublin III Regulation. The fact that those instruments have proven beyond any reasonable doubt to be ineffective from the perspective of solidarity and fair sharing, as well as the

78 Judgement 26 July 2017, Jafari, C-646/16, EU:C:2017:586.

79 Jafari, $\$ \$ 87-92$.

80 Jafari, $\$ \$ 84,89$.

81 Jafari, \$\$ 94-100.

82 That is, the mechanism for early warning, preparedness and crisis management.

83 Directive 2001/55/EC of the Council, of 20 July 2001, on minimum standards for giving temporary protection in the event of a mass influx of displaced persons and on measures promoting a balance of efforts between Member States in receiving such persons and bearing the consequences thereof (OJ L 212, of 7 August 2001, p. 12). 
ability to secure quick access to a fair asylum procedure, seems to be unknown to the Court: With all due respect, this is quite disappointing. It seems difficult to resist the temptation to qualify the reasoning followed by the judges as a formalistic one.

At the same time, it must be admitted that the position of the Court was not easy. The inability of the first country of entry criterion to address a massive inflow of displaced persons was self-evident, as it has always been: However, it was equally clear that affirming a jurisprudential allocation criterion based on a substantially free choice would not have led to a more rational and undisputed setting. It is up to the legislature to draw a different framework, taking into due account the guiding principles of asylum policy and the lessons learnt. Plainly, it was not correct to expect that the judgement could take the shape of a blueprint for the reform of the Dublin system. In the same time, some principled statement, even in the form of a targeted obiter dictum, would have been very welcome ${ }^{84}$.

At first sight, a risk might thus be conceived that any attempt to revise the tenets of the Dublin III Regulation might now be qualified by some of the interested actors as superfluous in light of the somewhat neutral approach followed by the Court, especially if contrasted with the bold stance Advocate General. Nevertheless, a closer look at the judgement suggests that the Court in Jafari did not completely renounce playing a role. In a final passage of the judgement, the Grand Chamber fully endorsed a recent

84 The issue might be raised of whether the Court, in the future, might reverse its prudent stance and be ready to declare the invalidity of art. 13 Dublin III Regulation based on its inconsistency with arts. 78 and 80 TFEU, which would eventually be read in conjunction with a constructive interpretation of art. 18 EUCFR. The doubt advanced above on the unfair consequences of such a move retains its validity in this scenario. Additionally, it must not be ignored that the whole current Dublin machinery is grounded on a certain logic for the allocation of competence, and eliminating the first entry criterion would mean a rewriting of the system. Only a complex exercise of legislative and policy choices could replace the current rules (i.e. the various allocation criteria and the related aspects, such as the procedures and compensatory measures). This means that even in the more pro-active hypothesis, the Court would be obliged, after having declared art. 13 (or the whole Regulation) invalid, to suspend the effects of this decision until the EU legislature has adopted a new regulation. On the ground, the situation would not change, although it must be admitted that from this perspective, the Court would symbolically exert a primary role in shaping the future features of the Dublin system, putting the abovementioned primary principles (too often forgotten) at the centre of the debate. 
shift in the case law, operated by the Fifth Chamber in $C . K{ }^{85}$, recalling that "under the second subparagraph of Article 3(2) of the Dublin III Regulation and Article 4 of the EUCFR, an applicant for international protection must not be transferred to the Member State responsible where that transfer entails a genuine risk that the person concerned may suffer inhuman or degrading treatment within the meaning of Article 4 of the Charter". As a consequence, "such an applicant cannot therefore be transferred if, following the arrival of an unusually large number of third-country nationals seeking international protection, such a risk existed in the Member State responsible" 86 . This passage should not go overlooked. First, the Court is definitely recognising that the Dublin allocations cannot ignore the individual risks to the applicants, even under the threshold of "systemic flaws" specified in art. 3 (2) Dublin III Regulation. Second, the Court, although in a sober fashion, is sending a clear message to the EU legislature: When a national asylum system is under a severe strain (not necessarily reaching the highly-demanding threshold of a systematic failure), the other EU MSs cannot pretend to enforce the first country of arrival criterion, thus opening the way to a different allocative output. It follows from the foregoing that the full respect for human rights emerges as a growing obstacle to the maintenance of the Dublin logic.

If some anarchy and uncertainty must be avoided, the legislature is called to seriously think about another approach for allocating competence to the various MSs. Interestingly, on the same day as Jafari, the Court issued its judgement in Mengestea $b^{87}$, purporting an applicant-sensitive reading of the time-limits for making a take charge request and thus transferring the responsibility to the originally competent MS. As a matter of fact, taking into account the usual duration of this kind of proceeding, the interpretation endorsed by the Court underlines the factual impossibility of enforcing the Dublin machinery as it stands. Again, a sober but unequivocal message is sent to the EU legislature: The structure needs a deep reform. Perhaps the Court might have been more courageous, but the judicial function, even at the constitutional level, does suffer from inherent limitations when complex policy choices are required in order to implement the principles embodied in primary law.

85 Judgement 16 February 2017, C. K. and Others, C-578/16 PPU, EU:C:2017:127, $\$ 65$.

86 Jafari, $\$ 101$

87 Judgement 26 July 2017, Mengesteab, C-670/16, EU:C:2017:587, \$\$ 44-74. 


\section{PARTY AUTONOMY: A CRITERION NOT FULLY SUITED FOR ASYLUM MATTERS}

As was mentioned earlier, a certain debate developed in the literature about the compatibility with the Geneva Convention of regional legislation reducing the scope of free determination by an asylum seeker about where to lodge his/her claim. However, the developments of international practice have shown that, under certain conditions, a system like the Dublin one may be deemed compatible with the Geneva Convention inasmuch as the latter would not afford a fully-fledged subjective right to choose a specific asylum country $^{88}$. The EU MSs affirmed this conviction throughout the process of the conception of the Dublin Convention and in the subsequent drafting exercises of the two Dublin regulations, with the evident approval of the other political institutions involved in the decision-making process (i.e., the Commission and the European Parliament). Lately, the same Court of Justice took a confirmative stance of such a reading of the Convention ${ }^{89}$.

What is now observed does not impede a discussion of a party autonomy or "free choice" approach from another point of view, one of efficiency and opportunity giving regard to the founding principles of the CEAS and the poor performance of the current rules on competence allocation. From this perspective, some NGOs and experts have proposed or deemed practicable giving a decisive role to the personal preferences of asylum seekers in the context of the Dublin system ${ }^{90}$, essentially for the sake of pragmatism and in light of the fact that usually, the subjective choice is motivated by the existence of some substantive link with the favoured country: This would maximise the asylum seekers' trust in and agency within the CEAS and would minimise the coercive features of the current provisions.

In considering the general features of the allocation of competence in international settings - discussed above (section II) — it must be acknowledged that in many fields of private international law, a growing role is recognised for the autonomy of private parties in identifying the competent court for settling legal claims or, in the alternative, for making recourse to arbitration ${ }^{91}$.

88 See supra, section III.2.

89 Judgement 6 September 2017 (Grand Chamber), Slovakia and Hungary v. Council of the European Union, joined cases C-643/15 and C-647/15, EU:C:2017:631, \$\$ 338-342.

90 See, for instance, Brandl (2004: 69); Carlier and Crépeau (2011: 665); ECRE (2008: 29-30); Human Rights Council (2015: \$ 66); Maiani (2016b: 46-49); ProAsyl et al. (2013).

91 The same happens for the identification of the applicable law. 
However, this does not usually happen in cases in which the legal proceedings refer to inalienable rights or personal status relevant to the enjoyment of public law rights. Moreover, the criteria for determining adjudicative power in criminal or administrative matters are defined by legal provisions according to the public interest and do not give room to the preferences of the individuals concerned. Given that the assessment of asylum claims is functional for the enjoyment of public law status and is often framed as an administrative law procedure, it would seem inappropriate to recognise the choice of the applicant as having a primary role for assigning competence to a given State.

In addition to that, two further aspects are, in my view, unconvincing in the "free choice" approach: 1) no public system for the reception and integration of forced migrants can avoid fixing some limits to its capacity ${ }^{92}$; 2) personal preferences are not only due to the existence of reasonable connections, but also to other considerations ${ }^{33}$, whose ultimate effects could negatively impact the most generous or efficient national systems and indirectly reward the most restrictive and inefficient States, contrary to the principle of solidarity and fair sharing of responsibilities (art. 80 TFEU) and to the need to offer an appropriate status to applicants in line with the Geneva Convention and other relevant treaties (art. 78 TFEU).

If it is true that a perfect approach does not exist, and that some form of corrective method should be envisaged in any case, as correctly noted by Maiani (2016b: 47) ${ }^{94}$, it is equally true that merely subjective choices may produce a sort of anarchy (which is unaffordable even for the most efficient State system) and could adversely affect the national budgets and the socio-economic environment of the MSs and of the whole EU. Thus, what appears to be a pragmatic and non-dogmatic approach could easily turn into disorder and fuel political tension. This being said, the rationale of this purported approach may be adequately accommodated — at least in part — in a

92 Considering the wide impact on the host society of high volumes of applicants (see above, section III), mere financial transfers from the EU or other MSs would hardly suffice as a compensatory measure.

93 The quality of the reception arrangements; the speed of refugee status determination and the recognition rate for a given nationality; the opportunity to find a well-remunerated job; the efficiency of the educational and health system; the information provided by informal networks, social media or even smugglers or "facilitators"; the concurrent closure or perceived "low quality" of other countries, etc.

For similar concerns about the "free choice" model, see also Guild et al. (2014: 17, 55); Guild et al. (2015: 56); Parusel and Schneider (2017: 128-129).

94 See also below, section III.4.2. 
scheme that achieves a more robust recourse to meaningful connecting factors and fully enforces art. 80 TFEU (below, section IV.4.2).

\section{THE "CLOSEST CONNECTION" CRITERION OR THE GENUINE LINK APPROACH}

As was outlined above (section II), in international law and in some areas of EU law, the allocation of competence (be it administrative or judicial) is usually guided or inspired by the idea that a substantial connection must exist between a State (including its legal order and socio-political community) and the persons or activities concerned. Additionally, the competent authority should be properly placed to be able to ascertain facts and manage the relevant procedure in an efficient and (hopefully) speedy way.

\subsection{Its possible meaning in asylum procedures}

What might this mean in the field debated here? Tacking stock of the drawbacks of the Dublin system identified so far (in section III, above) two aspects deserve attention. First, account should be taken - as much as possible - of the personal characteristics of the asylum seeker, of his or her ties with a given country and of the related potential for integration, in consideration of the need for the prospective refugee to build a new life. Second, the competent State should be selected giving regard to the need to manage the asylum claim in an accurate and quick way, with the cooperation of the applicant and possibly with the help of the surrounding social milieau (thus reducing the costs for first reception and for integration).

The idea of establishing competence under the Dublin system according to a genuine link approach is not new, although the rules so far adopted at the EU level have conceded little room for such logic, with an exception made for the partial relevance recognised for some (strict) family relations (above, section IV.1). For instance, UNHCR (1979: $\$$ h) has emphasised the need to take into account the connections between an asylum seeker and the country which should take charge of him/her. In the context of the discussions around the Dublin system, UNHCR (2011: 5) stressed that the "notion of meaningful links or connections includes family and cultural links, as well as legal residence in the Member State, but does not include the possession of a visa, or mere previous presence in that State's territory" ${ }^{\prime 2}$. Scholars have already

95 See also UNHCR (2016: 7), referring to family links, work or study links in a Member State, or knowledge of a language. 
advocated the recourse to such method. Byrne and Shacknove (1996: 206) enumerated the following connecting factors: the legal presence in a given territory of family members; prior periods of residence for professional or educational reasons; strong linguistic and cultural ties between the asylum-seeker and the putative asylum country; or the existence of a well-established expatriate community. Later, Maiani and Vevstad (2010: 144-145) referred to social networks in the broadest sense, linguistic affinities, and previous abode. Other experts have purported this view ${ }^{96}$. Specialised and authoritative NGOs have also voiced the need for a reconsideration of the Dublin logic ${ }^{97}$. In a consideration of secondary law, a significant reference to relevant connecting factors is traceable in the second decision on an EU-wide relocation scheme for the benefit of Italy and Greece ${ }^{98}$.

Sadly, in the Dublin IV proposal, the Commission did not sufficiently address this point and summarily disregarded the relevance of the personal characteristics of asylum seekers, showing in the reasoning a degree of confusion with the "free choice" approach". Notwithstanding this, it is perfectly conceivable to give more weight to objective links between an asylum seeker and a given MS,

96 See, for instance, Di Filippo (2015: 42-44, 55-56); Di Filippo (2016); Nascimbene (2016: 112); Pollet (2016: 95).

97 See Conference of European Churches (2016: 2-3); ECRE (2016: 5).

98 Decision (EU) 2015/1601 of the Council, of 22 September 2015, establishing provisional measures in the area of international protection for the benefit of Italy and Greece (OJ L 248, of 24 September.2015, p. 80). Recital No. 34 of this Decision reads as follows: "The integration of applicants in clear need of international protection into the host society is the cornerstone of a properly functioning CEAS. Therefore, in order to decide which specific Member State should be the Member State of relocation, specific account should be given to the specific qualifications and characteristics of the applicants concerned, such as their language skills and other individual indications based on demonstrated family, cultural or social ties which could facilitate their integration into the Member State of relocation" (emphasis added).

99 See COM (2016) 270 final, 4 May 2016, p. 13. The explanatory memorandum of the proposal underlines that, according to some MSs, the criterion of first entry must be preserved, and that alternative connecting factors (such as personal preferences) would add confusion and give the wrong signal that asylum seekers can choose their country of final destination. In the meantime, it is acknowledged that other MSs and relevant stakeholders have called for a different vision, focusing on the preferences or characteristics of asylum seekers. Nevertheless, the explanatory memorandum merges the personal preferences and the characteristics of asylum seekers in the same concept, and uses the same argument to discard both the "free choice" approach and the "personal characteristics" one. 
thus favouring the former's speedy and efficient integration and indicating the country which is better placed to hear the case.

As far as family ties are concerned, the need to embrace a wider vision of the concept of family, given the peculiarity of the context of forced displacement, was discussed above. It is true that this enlarged notion of family might appear "too generous" to some commentators or to several Member States. Nevertheless, it could serve both as a cost saving tool and as a guiding principle for solving the issue of the overburdening of specified States ${ }^{100}$. In the first instance, members of the nuclear family (including siblings) should be relevant. In the absence of any of them, the presence of relatives might work as a connecting factor towards other countries. In the case of reception strain in one of the possible destination States, another one where a relative is present would become competent ${ }^{101}$. In doing so, (wide) family ties play a role in implementing the principles of fair sharing and solidarity.

Another element to take into account is a previous study or work experience in a given MS, or another form of regular stay which is not merely transitional: Compared to the lack of any relevant "contact" with a national community, a previous regular residence is usually capable of facilitating the interaction with the asylum decision makers (and other authorities involved) and creating the potential for integration, unless it is ascertained that anti-social behaviours occurred during that stay.

Language skills are often invoked by the proponents of this approach. Some States whose official language is widely spoken outside of Europe (for instance, English, French or Spanish) might fear being penalised by this criterion. Nevertheless, this connecting factor could pragmatically work even to indicate a State where the population in general and civil servants in particular are usually fluent in a second language (for instance, English in some northern European countries) ${ }^{102}$.

A challenging ground is the presence of a private sponsor. This potential connecting factor may cause some concern in terms of the risk of abuse, false declarations or coverage of illicit smuggling networks, but it should at least be the object of a serious and open-minded discussion. A starting point might be represented by the good practices developed in countries which have

100 See also below, section IV.4.2.

101 The identification of the competent State when more relatives are present in the EU might be left to the applicant (if an adult) or might be done according to the best interest of the applicant (if a minor).

102 As for the risk of overburdening, see below, section IV.4.2. 
developed more experience in such field (i.e. Canada, Italy and France) ${ }^{103}$. In a globalised world, where transnational activities and personal mobility are physiological, a person may well act as a point of reference or a sponsor for a third-country national (TCN), for instance, due to a previous professional or personal exchange developed during a stay in Europe or even in third countries. Thus, in addition to relatives (see above), private individuals - whether they are EU nationals or TCNs regularly residing in the EU - may have a strong and verifiable personal link to an asylum seeker. A similar reasoning might apply to non-profit organisations or firms, subject to some eligibility requisites. In the different but comparable setting of legal avenues to reach the EU, the European Union Fundamental Rights Agency (2015: 6) recently argued that private sponsorship is one of the most promising and under-exploited means. The recourse to such a scheme would be even easier to implement in the context of intra-EU relocations, compared to transfers from other continents.

A further element that might be taken into account is the holding of professional qualifications or academic titles released by the institutions of the MSs or, if released by a third country, easily recognisable on the basis of legal tools facilitating such equivalence. The network of bilateral treaties already in force between the Member States and the third countries of origin and the current cooperation programmes in the field of education and training require a proper evaluation. In fact, they could offer pragmatic solutions whereby the then recognised refugee could play the role of a proactive economic actor, instead of depending heavily on public social assistance.

One may question which of these factors is more suitable and what pre-requisites should be established to put them in place. This is the task of the legislature: A decisive (and welcome) step in that direction has been taken by the European Parliament with the mentioned Wikström Report ${ }^{104}$. From

103 See Fratzke (2017); Kumin (2015); Yahyaoui Krivenko (2012).

On the pilot projects sponsored by religious entities in Italy, see Gois and Falchi (2017); Morozzo della Rocca (2017). France, and more recently, Belgium have followed this example (see https://goo.gl/jg3hgs). See also the New York Declaration, $\mathbb{\$}$ 79 and Annex I, \$\$ 10 and 14.

104 See, in particular, amendments 108-131. It must be noted that the need to obtain wide support among the political groups led the LIBE Committee to adopt a cautious version of links such as sponsorship (amendment 124), professional or educational diplomas (amendment 117), language skills or other socio-cultural ties (amendments 127-129). This choice might reduce the impact of the new approach in terms of applicants genuinely connected with a given MS, as pointed out, for instance, by Maiani (2017: 638). It would undoubtedly be preferable to have a more robust recourse to 
the viewpoint of the scholar, I deem it important to stress that new legal paradigms do exist and may be seriously explored in order to alter the current overall unsatisfactory performance of the Dublin rules.

\subsection{The risk of new imbalances and the need to give teeth to article 80 TFEU}

In applying this new approach, it must be acknowledged that a few Member States, which are already under strain as a result of having been more generous or open in the shaping of their migration or asylum policy in the past, might become the responsible country as a consequence of what has been described - although in the context of the free choice method - as a "snowball effect"105. In addition, it may well be that an applicant does not satisfy any meaningful connection with a MS: Thus, how this person should be allocated remains to be seen.

Notwithstanding their sounder rationale, the connecting factors discussed here, like the others described above, do not cover all the allocation needs and are not a panacea. A frank and unbiased discussion of the possible criteria reveals that they cannot act alone because their operational effects may produce, in any setting, unfair or inefficient results, including the engagement by Member States in free riding and burden shifting. In accordance with the lessons learnt, the decisive step is not to blindly opt for one allocative link or another. Rather, a preference for one or some of them (deemed per se more rational and sound) should always be accompanied by a framework in which fair sharing and solidarity are shaped as the inspiring principle of the system of allocation of asylum seekers, as required by art. 80 TFEU ${ }^{106}$ and solemnly reminded by the Court of Justice in the relocation dispute ${ }^{107}$. From this perspective, it is simply untenable for some States to undergo a relevant pressure (as frontline countries or as second-line favourite places of final destination), while others give scarcely relevant support, or no support at all. The fact that this issue is a politically sensitive one, with some MSs maintaining non-collaborative aptitudes, does not alter the circumstance that hosting asylum seekers and assuming responsibility is an obligation under international and EU

such criteria, but at the same time, the strong incentive to the MSs to accept applicants asking for the activation of such a connecting factor must be underlined, given the interest in filling their own share with persons who are easier to integrate in their respective societies (see infra, section IV.4.2).

105 Williams (2015: 22).

106 In a similar vein, see Advisory Committee on Migration Affairs (2015: 33, 37-38); De Bruycker and Tsourdi (2016b).

107 Judgement 6 September 2017, EU:C:2017:631, \$\$ 252, 291. 
law binding all the MSs and that each designated MS carries out this task in the interest of the whole EU and of the entire Schengen area. In light of this, the allocation of competence must be organised in full compliance with art. 80 TFEU, covering the whole set of responsibilities ${ }^{108}$. This is not to say that persons must be shared as if they were objects, or that pragmatism must lead us to think that only a market-oriented method would be viable ${ }^{109}$. Rather, taking into account the imperatives of EU primary law, a balanced combination of a fair division of labour among the MSs, rational competence criteria, and appropriate cooperative mechanisms among the relevant actors (national authorities and applicants) must be devised.

Initially, a weighting mechanism should be conceived, leading to attribute to each MS a fair share of potential applications. This method is far from being a novelty in EU law, being practiced in different fields: voting power in the Council, number of seats in the European Parliament, contribution to the EU budget, distribution of EU funds, etc. The Commission ${ }^{110}$ and the European Parliament ${ }^{111}$ have already preconised this idea, although with some

108 From this perspective, the idea that solidarity could be declined according to a varying content, depending on the unilateral availability of each MS, was put forward in November 2016 by the Visegrad countries (coordinated by the Slovak rotating presidency of the EU Council), under the heading of "effective solidarity" or "flexible solidarity": see the Joint Statement of the Heads of Governments of the V4 Countries of 16 September 2016 (https://goo.gl/Bwiv3M) and the "Non Paper" of the Slovakian Presidency released in November 2016 (https://goo.gl/vclOHs). This view is untenable. Processing asylum claims, organising a first reception system, managing the stay of recognised refugees or the situation of denied applicants: all these activities impinge on the national budget, the public administration, the judiciary, the territory and the society as a whole. It is simply absurd to think that only certain States should take charge of all these headings, while others could confine themselves to deploying specialised personnel or providing some financial contribution. More than an effective solidarity, this idea resembles another vision, i.e. one of "variable unilateralism".

109 See, for instance, the model developed by Fernández-Huertas Moraga and Rapoport (2014).

110 See "Proposal for a Regulation establishing a crisis relocation mechanism and amending Regulation (EU) No 604/2013 of 26 June 2013 establishing the criteria and mechanisms for determining the Member State responsible for examining an application for international protection lodged in one of the Member States by a third country national or a stateless person”, COM (2015) 450 final, 9-9-2015. See also the Dublin IV proposal.

111 See "Resolution of 12 April 2016 on the situation in the Mediterranean and the need for a holistic EU approach to migration (2015/2095(INI))", A8-0066/2016, 12-42016, \$\$ 33-38; Wikström Report, pp. 112-114. 
variations. Which criteria should concur to determine the shares and their relative weight may be subject to discussion ${ }^{112}$, but the overall idea is defensible and fully in line with arts. 78 and 80 TFEU. Here it is emphasised that - thanks to the shaping of allocation criteria that are robustly inspired by a meaningful connections approach - each MS would be authorised and encouraged to fill its share with asylum seekers having a connection with the country, in order to reduce the difficulties in their integration, conduct a quicker procedure in an applicant-friendly environment and, finally, minimise the impact on the national budget and the local society ${ }^{113}$. To put it differently, the MSs should not consider mandatory shares or quotas as an inadmissible threat to their sovereignty. Rather, they form a component of a more complex construction aimed at minimising the negative impact for every EU country in the fulfillment of pre-existing legal obligations and preserving the integrity of the Schengen area, which has otherwise been jeopardised by the disappointing record of the current Dublin system ${ }^{114}$.

The discussion of mandatory shares makes sense only if the overall picture is taken into due account. In order to depoliticise this matter, a description of the possible functioning of a new allocative machinery proves useful, drawing some inspiration by the positions advanced by the Commission (in the Dublin IV proposal) and the European Parliament (in the Wikström Report) and tacking stock of the experience accumulated by the EASO. The applications lodged in the whole EU would be collected through an automated and centralised system, which would monitor, in real time, the evolution of the situation. The individual applicant would be allocated to the MS with which a genuine link exists. Absent a substantial connection with one Member State, or if the designated country has already exceeded its assigned share ${ }^{115}$ and no other MS has a (lesser) connection with the applicant, the only reasonable default criterion should be to designate a country which is not performing its assigned share, in accordance with art. 80 TFEU and the need to quickly identify a competent State. In order to give limited but equally significant room to the asylum seeker's inclination, the latter might be given the possibility to choose among the countries which are below their share of

112 For a detailed assessment of the main proposals advanced in the public debate (and of the possible outcomes in terms of shares assigned to each MS), see Parusel and Schneider (2017: 49-67).

113 For some interesting remarks from that perspective, see Thielemann (2018: 79-80).

114 For an economic analysis sharing a similar perspective, see Rossi (2017).

115 An exception should be made for family members, especially if minors are involved. 
allocations ${ }^{116}$. With the view to facilitate this choice, the option to employ a matching tool, such as the one developed by the EASO in support of the relocation process from Greece, might be explored ${ }^{117}$.

In order to stay pragmatic, it must be highlighted that one of the main elements of mistrust by asylum seekers towards the current Dublin system is the risk of being obliged to stay or move to a country with which they do not have any substantial link. Under the proposal formulated above (section IV.4.1), which significantly expands the relevance of the meaningful connecting criteria, this risk is significantly reduced. However, the possibility still exists for an applicant to be allocated to a MS under the default criterion of the country that has not yet honoured its assigned rate. In the meantime, the Member States with limited experience in hosting asylum seekers often express an explicit or implicit resistance to accepting foreigners (regardless of whether they are entitled to international protection) under a compulsory scheme.

In order to address these possible sources of tension, the option suggested above (the chance for the applicant to choose among the MSs under their share and the employment of a matching tool) might be a first device to limit such possible discomfort ${ }^{118}$. Second, and even more decisively, a qualified freedom of movement of the beneficiary of international protection ${ }^{119}$ might be envisaged, according to the following terms. If after the recognition of refugee status or subsidiary protection by the designated MS the beneficiary receives an effective job offer in another MS, and the security checks are fulfilled, he or she should be entitled to accept it while the prospective host country should not be allowed to apply the "Community preference" or similar protectionist measures. Three positive effects could be accumulated: a better allocation of the workforce, recuperation of some consideration for the self-determination of the refugee, and the recognition of the legal value

116 The Wikström Report provides for the drafting of a list of four States with the lowest number of applicants relative to their share, among which the applicant would be allowed to choose the destination country: see amendments 172-173. As aptly underlined by Maiani (2017: 639), it would be more convenient to widen the choice among all the MSs "below quota".

117 See https://www.easo.europa.eu/easo-matching-tool.

118 The expressed preference would give some assurance of the will to develop a positive relationship with the host country, especially if oriented by a matching tool.

119 The issue is not new and has been repeatedly evoked by qualified NGOs and experts - in the context of a broader discussion on the transfer of international protection status - as a tool for addressing the failures of the Dublin system: see inter alia European Council of Refugees and Exiles (2014); Favilli (2015); Peers (2012). 
of his or her economic proactivity (where present $)^{120}$. The legal basis for such qualified freedom of movement for work purposes would derive from art. 79 (2) (b) TFEU ${ }^{121}$ (read in conjunction with art. 45 (2) EUCFR), and might be translated into an extension of the scope of some provisions of Directive 2004/38/EC (valid for EU nationals) ${ }^{122}$, or in the enactment of ad hoc provisions, which might be inspired (with some adjustments) by arts. 14-23 of the Directive 2003/109/EC on third-country nationals ${ }^{123}$. From this perspective, such freedom of movement would also contribute to providing (at least partial) substance to the call for a "uniform status of asylum for nationals of third countries, valid throughout the Union", contained in art. 78 (2) (a) TFEU. The issue should be raised as to whether, after voluntary establishment in another MS, the protection duties should continue to bind the original MS or should be transferred to the second one ${ }^{124}$, or whether such duties should simply cease.

Be that as it may, the combined effects of mandatory (but proportionate) shares for each MS, genuine links as the primary allocation criteria, a limited right of choice and a qualified freedom of movement for the applicants might

${ }^{120}$ For a similar approach, see Advisory Committee on Migration Affairs (2015: 39, 6061); Den Heijer et al. (2016: 611-612); Parusel and Schneider (2017: 129-130).

121 The different legal basis employed for the reform of the Dublin system (art. 78 (2) (e)) might explain the absence of this issue from the Commission's proposal and from the Wikström Report. However, given the identity of legislative procedure applicable, an act being based on both the legal basis is conceivable.

122 Directive 2004/38/EC of the European Parliament and of the Council, of 29 April 2004, on the right of citizens of the Union and their family members to move and reside freely within the territory of the Member States (OJ L 158, of 30 April 2004, p. 77).

123 Directive 2003/109/EC of the Council, of 25 November 2003, concerning the status of third-country nationals who are long-term residents (OJ L 16, of 23 January 2004, p. 44).

${ }^{124}$ For the discussion of this topic, see E. Guild et al. (2015: 39-51, also for additional references). Lately, it has been proposed by Mitsilegas (2017: 736-738) that a robust regime of mutual recognition of positive asylum decisions should be affirmed, including the transfer of protection duties to the receiving MS and the equal treatment with refugees therein already recognised as such. Although sharing the call for the introduction of devices that make mutual recognition in the CEAS more refugee-sensitive, I am afraid that linking the transfer of protection duties to a second MS to the sole will of the recognised holder of international protection (as Mitsilegas seems to suggest) would pave the way to an excessive burden for some MSs, thus raising the issue of the correct implementation of art. 80, as pointed out when discussing the free choice approach in general terms (above, section IX). 
have three concurrent beneficial effects: 1) depriving of substance the aprioristic opposition by some Governments to a more rational and a fairer distribution of tasks throughout the Schengen area; 2) eliminating the temptation for some MSs to play a burden-shifting game against other MSs; 3) properly addressing the legitimate call — shared by, inter alia, Costello (2016: 275) and Maiani (2017: 641-644) — to devise a Dublin system that eliminates its most evident coercive features and is thus able to gain the trust and cooperation of applicants.

\subsection{Procedural issues and standard of proof}

As repeatedly recalled herein, the lessons learnt from other legal settings treating the allocation of competence must be kept in mind. Thus, a critical discussion regarding new or different criteria cannot avoid taking into account the need to address the issue of the procedural implementation of the criteria and of the feasibility of the same, according to the overall exigency of efficiency and coherence.

From this perspective, a strong objection to a genuine link approach might be the following. The criteria based on family ties or on other elements (such as having first entered another country), currently specified in the Dublin III Regulation, did not work well in practice due to the administrative difficulties in managing communications between different State administrations and in relying on declarations not often supported by official documentation. If this occurred with (strict) family ties, things might only worsen if broader meaningful links - whereby the number and nature of relevant circumstances to verify are even greater - were specified in a new Dublin Regulation. To put it differently, the approach based on a wide array of meaningful links could prove unrealistic, stretching the already stressed bureaucratic machinery.

However, this argument is not fully convincing. First, what has impeded inter-State cooperation on family ties (in the Dublin II and III versions) or other factors from working is, by and large, the conflictual situation in which the Member States are placed under the current Dublin fabric: as Maiani (2016a: 110-111) well explains, the cause of the insufficient cooperation among the MSs is deep in the structure and ethos of the Dublin System, centred on transferring applicants elsewhere and thus creating winners and losers in a game in which national interests are pitted one against the other. If the innovative idea of a system of shares is enacted, then the MSs will be stimulated to fully exploit the chance to fill their own shares with persons who are likely to create fewer concerns. Second, any allocative machinery must be designed based on the acceptance of the idea that 
asylum seekers are often persons who have fled from dramatic contexts without a concrete chance to prepare a fully-fledged dossier to face the Dublin or RSD procedures. Such procedures are different from civil or criminal law litigation with the related standard of proof. In asylum proceedings, a pragmatic procedural approach must be adopted if the purpose of the Geneva Convention and other primary sources (the ECHR, the TFEU and the EU Charter) are not to be frustrated ${ }^{125}$. At least to a certain extent, the "Dublin stage" must be adapted to such an evidentiary approach, as it is merely ancillary to the main RSD procedure. For this reason, any revision aimed at introducing more suitable connecting factors cannot avoid endorsing the idea that an inter-State procedure must be inspired by a prima facie or fast-track approach ${ }^{126}$ in order to work effectively. From this perspective, it should not be forgotten that in any area in which the EU has pursued the objective of realising an integrated or common space, simplified mechanisms of dialogue between State authorities and generous recourse to the techniques of mutual recognition have been developed. It is sufficient to consider administrative fields such as the ones discussed above (section II) or the mutual recognition of professional titles and qualifications. In the context of the EU area of freedom, security and justice mention can be made of transnational civil and commercial proceedings and of the police and judicial cooperation in criminal matters ${ }^{127}$.

The recent stance adopted by the EU institutions seems to move in the right direction. According to the Wikström Report, any applicant should present a claim in the first country of arrival and submit to an identification process. At the same time, the application would be registered under a European database. The authorities of this first country of arrival would then conduct a personal interview, pursuing two concurrent aims: ascertaining the prima facie presence of connecting factors (i.e. the genuine links mentioned above) with one or more EU Member States and verifying the security issues ${ }^{128}$. The authorities of the potentially designated Member State

125 A thorough analysis of this issue is not possible here. Inter alia, see Goodwin-Gill and McAdam (2007: 53-60); Noll (2005); UNHCR (2011, \$\$ 195-205); UNHCR (2013)

126 Sadly, light evidentiary requirements and accelerated procedures seem to be welcomed by States or by the EU only if they are aimed at refusing to grant protection: see, for instance, Costello and Hancox (2016); Reneman (2013).

127 For a similar perspective, see Mitsilegas (2017: 725, 732-734).

128 Contrary to what often happens with the Dublin III Regulation, cooperation with identification and the mentioned evaluations is to be expected, thanks to the advantages for the asylum seeker from the perspective of being allocated to a State that is 
would be called upon to cooperate in order to conduct such prima facie verification in the least possible time (even exploiting the possibilities offered by modern technologies, existing tools and EASO facilitation) ${ }^{129}$. In order to discourage mala fide behaviours by the claimants, a rule would be introduced according to which - if the designated State later finds that the claimed substantial link does not correspond to reality — the person will be allocated through the centralised system to another country, in a casual manner ${ }^{130}$.

The Member State - which is genuinely connected with the asylum seeker - shall accept the allocation of the asylum seeker and will complete the examination of the asylum claim ${ }^{131}$. In order to reassure MSs other than frontline countries, it is indispensable to underline that a burdensome part of any procedure for the application's assessment (the identification and tracing of family members) would already have been completed with the highly probable cooperation of the interested person. Moreover, the existence of family and/or social ties in the host country would make the management of the rest of the procedure and the prospective process of integration into the host society easier and quicker, reducing the room for social tensions and populist or xenophobic propaganda. As already specified (see above, section IV.4.2), applicants not connected to any MS should be quickly allocated to one of the MSs which is "below quota" chosen by themselves.

Whether the solution proposed here would produce lengthy procedures or an excessive administrative burden on the first MS of entry may be questioned. The issue of the speed of the procedure has already been addressed, if a genuine link approach and a prima facie assessment procedure are endorsed. Moreover, we must wonder what the alternatives are. Under the current

presumably more appropriate (see above, section IV.4.1). At the same time, the length of procedures will be reduced and thus also the associated costs (now present) of hosting or controlling persons whose identity or status is far from clear.

129 See the Wikström Report, amendments 28 and 151.

130 See the Wikström Report, amendments 151-152.

131 As an alternative, it might be conceived that the country where the claim is lodged will carry out the evaluation of the asylum claim. Were a positive decision to be awarded, it would gain automatic recognition in the country of destination. In this way, however, a heavy burden could be put on the few States interested by first entry (or disembarkation), which are already under a severe strain. Moreover, during the evaluation period of the claim and the possible supplementary period of the decision of the legal recourse against a possible denial, the asylum seeker would be obliged to stay in a country where he/she could have no substantial links, with the inconveniences mentioned above (supra, section III). 
Dublin III Regulation, the country of first entry is already obliged to conduct significant administrative activity regarding the registration of the claim, the determination of the competent State and subsequent steps: a file is created, human resources are employed, time is spent on this activity, an interview is conducted, the asylum claimant is hosted somewhere, and reception conditions must be guaranteed. The European Parliament is proposing to transform this early stage into a step showing a friendly face to the applicant. The relevant administrative activities would be greatly facilitated by the asylum seeker's cooperation, while a different scenario would probably lead to a form of legal challenge by the applicant or to his/her absconding. In my opinion, the solutions elaborated by the EP deserve careful consideration, and it would be advisable for the Governments (meeting in the Council and in its preparatory bodies) to conduct an unbiased and open-minded discussion on this complex dossier.

\section{CONCLUSION}

The Dublin system can and must emerge from its isolation from other areas in which competence is assigned to States and enter a phase of maturity. The guiding principles of the CEAS (including fair sharing and solidarity) must receive primary consideration in the drafting of EU rules governing the allocation of competence in asylum procedures. Stronger recourse to meaningful links and the assignment of permanent allocation shares to all MSs are indispensable and mutually reinforcing devices for pursuing a true overhaul of the current disappointing Dublin fabric.

At the same time, it must be underlined that a modification of the allocative criteria and the definition of mandatory shares cannot be pursued in isolation. Such processes should proceed together with the revision of the procedural rules (in harmony with the peculiarities of asylum matters and after first looking at simplification) and the resumption of the debate on a regime of economic freedom of movement for recognised refugees.

The approach discussed here and many of the solutions envisaged in the Wikström Report could reduce tensions among the Member States on the debated topic of burden sharing, purporting a rational and pragmatic way to establish a balance between the needs and aspirations of the asylum seekers and the needs of the Member States (both the frontline ones and the others). It would render the asylum seeker a co-protagonist in the procedure, discouraging elusive conduct and promoting cooperative behaviour. The applicant will have no need to abscond and conduct a de facto rebellion against the system in force, or at least will not able to invoke a reasonable excuse for doing it. 
As I tried to demonstrate, it is hard to believe that a new approach would make things more complicated or burdensome for the national services: Entirely to the contrary, it would bring some order to a chaotic situation and would reduce the grounds for the sterile recriminations between the Member States. Moreover, the scarce public funds might be better addressed and used, without the unnecessary waste of money and time. This way, a new Dublin system would also be a useful tool for addressing the relevant concerns of public opinion, dismantling specious arguments and rebuilding confidence in the governance abilities of the EU and its Member States.

In contrast, the maintenance of the traditional Dublin logic (although with some innovations, such as a permanent corrective mechanism) ${ }^{132}$ would reproduce the defects and bad practices of the current legislative framework (widely described above in section III), to the benefit of two categories of interested 'stakeholders': smugglers and populists.

Last but not least, I am aware that a robust discussion is urgently needed regarding protection-sensitive external action on asylum (tackling inter alia the issue of the legal avenues to access Europe for the applicants ${ }^{133}$ ) and the translation into an operative formula of the target - too often forgotten by the EU legislature - of a "uniform status of asylum for nationals of third countries, valid throughout the Union" (art. 78 (2.a) TFEU): These topics, however, go far beyond the limits of this contribution.

132 The approach endorsed by the European Parliament in the Wikström Report — although some integration might be desirable — appears convincing, insofar as it proposes a real overhaul of the current system. On the contrary, sadly, the stance of the Commission and of some Governments presents the defect to stop halfway in the implementation of the guiding principles of the CEAS and in the acknowledgement of the structural defects of the system. In fact, it envisages a mix of the known criteria with a corrective relocation mechanism (voluntary in normal circumstances and mandatory in situations of serious crisis). For a synthesis of these lines, see Communication of the Commission, "Commission contribution to the EU Leaders' thematic debate on a way forward on the external and the internal dimension of migration policy", COM (2017) 820 final, 7.12.2017, p. 6.

133 In order to promote a virtuous circle between intra-EU fair sharing and the EU contribution toward alleviating the pressure on non-EU countries of first asylum, it could be foreseen that the shares might also be filled with asylum seekers admitted under resettlement schemes or other legal humanitarian channels. From this perspective, it seems commendable that the Wikström Report proposes to include such persons in the automated system for the collection of applications and in the calculations for the fulfilment of the relevant shares: see amendments 25 and 46 . 


\section{Bibliography}

Acosta Sánchez, M. A. (2017). Inmigración marítima en el Mediterráneo: las iniciativas de la UE y la protección de los derechos humanos. Anuario de los Cursos de Derechos Humanos de Donostia-San Sebastián, 17.

Advisory Committee on Migration Affairs (ACVZ). (2015). Sharing responsibility. A proposal for a European Asylum System based on solidarity. The Hague: Advisory Committee on Migration Affairs, December 2015. Available at: https://goo.gl/ PCnLa3.

Basilien-Gainche, M. L. (2011). La politique européenne d'immigration et d'asile en question: la valeur de solidarité soumise à l'argument de réalité. In C. Boutayeb (ed.). La solidarité dans l'Union européenne. Eléments constitutionnels et matériels (pp. 245-258). Paris: Dalloz.

Biscottini, G. (1964). Diritto amministrativo internazionale - Vol. 1. La rilevanza degli atti amministrativi internazionali. Padova: Cedam.

Bodart, S. (2018). Article 18 - Droit d'asile. In F. Picod and S. van Drooghenbroeck (eds.). Charte des droits fondamentaux de l'Union européenne (pp. 415-443). Brussels: Bruylant.

Brandl, U. (2004). Distribution of Asylum Seekers in Europe? Dublin II Regulation determining the responsibility for examining an asylum application. In C. Dias Urbano de Sousa and P. de Bruycker (eds.). The Emergence of a European Asylum Policy (pp. 33-69). Brussels: Bruylant.

Byrne, R. and Shacknove, A. (1996). The Safe Country Notion in European Asylum Law. Harvard Human Rights Journal, 9, 185.

Caffio, F. (2018). Migranti: Frontex da Triton a Themis, Ue prova a regionalizzare. AffarInternazionali, 5-2-2018. Available at: https://goo.gl/iYdR1Y.

Cannizzaro, E. (2011). L'armonizzazione delle politiche di asilo in sede comunitaria e la Convenzione di Ginevra sui rifugiati del 1951. Rivista di diritto internazionale, 84, 440-442.

Capicchiano Young, S. (2017). DublinRegulation IV and the Demise of Due Process. Journal of Immigration, Asylum and Nationality Law, 31 (1), 34-50.

Carlier, J. Y. (2002). La place des ressortissants de pays tiers dans la Charte. In J. Y. Carlier and O. de Schutter (eds.). La Charte des droits fondamentaux de l'Union Européenne (pp. 179-200). Bruxelles: Bruylant.

— and Crépeau, F. (2011). Le droit européen des migrations: exemple d'un droit en mouvement? Annuairefrançais de droit international, 57, 641-674.

Cassese, A. (2001). International Law. Oxford: Oxford University Press.

Chetail, V. (2016a). Looking Beyond the Rhetoric of the Refugee Crisis: The Failed Reform of the Common European Asylum System. European Journal of Human Rights, 584-602.

- (2016b). The Common European Asylum System: Bric-à-bracor System? In V. Chetail et al. (eds.). Reforming the Common European Asylum System. The New 
European Refugee Law (pp. 1-38). Leiden/Boston: Brill/Nijhoff. Available at: https://doi.org/10.1163/9789004308664_002.

Conference of European Churches. (2016). Comments on the European Commission's proposal for a Dublin IV Regulation, October 2016. Available at: https://goo.gl/ EzMzQx.

Costello, C. (2016). The Human Right of Migrants and Refugees in European Law. Oxford: Oxford University Press.

and Hancox, E. (2016). The Recast Asylum Procedures Directive 2013/32/

EU: Caught between the Stereotypes of the Abusive Asylum Seeker and the Vulnerable Refugee. In V. Chetail et al. (eds.). Reforming the Common European Asylum System: The New European Refugee Law (pp. 377-441). Leiden/Boston: Brill/Nijhoff. Available at: https://doi.org/10.1163/9789004308664_014.

De Bruycker, P. and Tsourdi, E. (2016a). Building the Common European Asylum System beyond Legislative Harmonisation: Practical Cooperation, Solidarity and External Dimension. In V. Chetail et al. (eds.). Reforming the Common European Asylum System. The New European Refugee Law (pp. 471-538). Leiden/Boston:Brill/Nijhoff. Available at: https://doi.org/10.1163/9789004308664_016. (2016b). The Bratislava Declaration on migration: European irresponsibility instead of solidarity. Eumigrationlawblog.eu [blog], 27-9- 2016. Available at: https://goo.gl/2q6Y7U.

Del Valle Gálvez, J. A. (2016a). Los refugiados, las fronteras exteriores y la evolución del concepto de frontera internacional. Revista de Derecho Comunitario Europeo, 20, 759 .

Den Heijer, M. (2014). Article 18 - Right to Asylum. In S. Peers et al.(eds.). Commentary on the EU Charter of Fundamental Rights (pp. 519-541). Oxford and Portland: Hart. Available at: https://doi.org/10.5771/9783845259055_562.

, Rijpma, J. J. and Spijkerboer, T. (2016). Coercion, Prohibition, and Great Expectations: The Continuing Failure of the Common European Asylum System. Common Market Law Review, 53, 607-642.

Di Filippo, M. (2014a). Delinking the acceptation of disembarkation and the assumption of responsibility for asylum seekers rescued at sea. Position Paper submitted on behalf of the International Institute of Humanitarian Law to the UNHCR High Commissioner's Dialogue on Protection Challenges, 2014 - Protection at Sea. Available at: https://goo.gl/zPc69T.

— (2014b). Irregular Migration and Safeguard of Life at Sea: International Rules and Recent Developments in The Mediterranean Sea. In A. del Vecchio (ed.). International Law of the Sea: Current Trends and Controversial Issues (pp. 9-28). The Hague: Eleven.

- (2015). Le misure sulla ricollocazione dei richiedenti asilo adottate dall'Unione europea nel 2015: considerazioni critiche e prospettive. Diritto, immigrazione, cittadinanza, 2, 33-60.

(2016). Dublin 'reloaded' or time for ambitious pragmatism? Eumigrationlawblog.eu [blog], 12-10-2016. Available at: https://goo.gl/U9hHsB. 
- (2017). An International Law Oriented Approach to the Allocation of Jurisdiction in Asylum Procedures. In E. Triggiani et al. (eds.). Dialoghi con Ugo Villani (pp. 451-460). Bari: Cacucci.

Dowd, R. and McAdam, J. (2017). International Cooperation and Responsibility-Sharing to Protect Refugees: What, Why and How? International and Comparative Law Quarterly, 66, 863-892. Available at: https://doi.org/10.1017/ S0020589317000343.

Durieux, J.-F. (2009). Protection Where? — or When?: First asylum, deflection policies and the significance of time. International Journal of Refugee Law, 21, 7580. Available at: https://doi.org/10.1093/ijrl/een043.

European Council of Refugees and Exiles. (2008). Sharing Responsibility for Refugee Protection in Europe: Dublin Reconsidered. Brussels. Available at: https://goo.gl/ saVHnm.

- (2014). Discussion paper: Mutual recognition of positive asylum decisions and the transfer of international protection status within the EU. Brussels. Available at: https://goo.gl/hRAkcT.

— (2016). Comments on the Commission Proposal for a Dublin IV Regulation. Brussels. Available at: https://goo.gl/yo3uDZ.

European Union Agency for Fundamental Rights. (2015). Legal entry channels to the EU for persons in need of international protection: a toolbox. Wien: European Union Agency for Fundamental Rights. Available at: https://goo.gl/rHE7m9.

- (2018). Periodic data collection on the migration situation in the EU. February Highlights (1 December 2017 to 31 January 2018). Wien: European Union Agency for Fundamental Rights. Available at: https://goo.gl/PYiUmX.

Favilli, C. (2015). Reciproca fiducia, mutuo riconoscimento e libertà di circolazione di rifugiati e richiedenti protezione internazionale nell'Unione Europea. Rivista di diritto internazionale, 88, 701-747.

- (2017). La crisi del Sistema Dublino: quali prospettive?. In M. Savino (ed.). La crisi migratoria tra Italia e Unione europea (pp. 279-301). Napoli: Editoriale Scientifica.

Feraci, O. (2013). Il nuovo regolamento "Dublino III" e la tutela dei diritti fondamentali dei richiedenti asilo. Osservatorio sulle fonti, 2, 1-37. Available at: https://goo.gl/FQTrwF.

Fernández Arribas, G., Halcón Lerdo de Tejada, Á. and Serrano López, I. (2016). Violación del derecho a solicitar asilo. La respuesta de Hungría a la crisis de los refugiados. Revista de Estudios Europeos, 67, 101-121. Available at: https://goo. $\mathrm{gl} / 7 \mathrm{MNNwY}$.

Fernández Arroyo, D. P. (2006). Compétence exclusive et compétence exorbitante dans les relations privées internationals. Collected Courses of the Hague Academy of International Law, 323, 9.

Fernández-Huertas Moraga, J. and Rapoport, H. (2014). Tradable Refugee-Admission Quotas and EU Asylum Policy. Bonn: IZA Discussion Paper no. 8683. Available at: https://goo.gl/q4NPAb. 
Fratzke, S. (2015). Not Adding Up: The Fading Promise of Europe's Dublin System. Brussels: Migration Policy Institute Europe. Available at: https:/goo.gl/E2Tdki.

(2017). Engaging Communities in Refugee Protection: The Potential of Private Sponsorship in Europe. Brussels: Migration Policy Institute Europe. Available at: https://goo.gl/VfvkuT.

Gaja, G. (2014). La compétence des États dans l'examen des demandes d'asile. In B. Bonafe et al. (eds.). The limits of international law - Essays in honour of Joe Verhoeven (pp. 139-145). Brussels: Bruylant.

Garlick, M. (2016). The Dublin System, Solidarity and Individual Rights. In V. Chetail et al. (eds.). Reforming the Common European Asylum System. The New European Refugee Law (pp. 159-194). Leiden/Boston: Brill/Nijhoff. Available at: https://doi.org/10.1163/9789004308664_008.

Gestri, M. (2011). La politica europea dell'immigrazione: solidarietà tra Stati membri e misure nazionali di regolarizzazione. In A. Ligustro and G. Sacerdoti (eds.). Problemi e tendenze del diritto internazionale dell'economia. Liber amicorum in onore di Paolo Picone (pp. 895-925). Napoli: Editoriale Scientifica.

Gil-Bazo, M. T. (2007). The Protection of Refugees under the Common European Asylum System: The Establishment of a European Jurisdiction for Asylum Purposes and Compliance with International Refugee and Human Rights Law. Cuadernos Europeos de Deusto, 36, 153-182.

- (2008). The Charter of Fundamental Rights of the European Union and the Right to be Granted Asylum in the Union's Law. Refugee Survey Quarterly, 27 (3), 33-52. Available at: https://doi.org/10.1093/rsq/hdn044.

Gois, P. and Falchi, G. (2017). The third way. Humanitarian corridors in peacetime as a (local) civil society response to a EU's common failure. Revista Interdisciplinar da Mobilidade Humana, 25 (51), 59-75. Available at: https:/goo.gl/ oxfjAd. Available at: https://doi.org/10.1590/1980-85852503880005105.

Goodwin-Gill, G. and McAdam, J. (2007). The Refugee in International Law (3 $\left.{ }^{\text {rd }} \mathrm{ed}.\right)$. Oxford: Oxford University Press.

Gortázar Rotaeche, C. J. (2009). El respeto a las libertades fundamentales (IV): el derecho de asilo y la protección en caso de devolución, expulsion y extradición. In J. M. Beneyto Pérez (ed.). Tratado de Derecho y Politica de la Unión Europea. Vol. 2 (pp. 609-638). Cizur Menor: Aranzadi-Thomson Reuters.

Gray, H. (2013). Surveying the Foundations: Article 80 TFEU and the Common European Asylum System. Liverpool Law Review, 34, 175-193. Available at: https://doi.org/10.1007/s10991-013-9138-8.

Guild, E. (1999). The impetus to harmonise: asylum policy in the European Union. In F. Nicholson and P. Twomey (eds.). Refugee rights and realities. Evolving International Concepts and Regimes (pp. 313-335). Cambridge: Cambridge University Press.

_ Costello, C., Garlick, M., Moreno-Lax, V. and Carrera, S. (2015). Enhancing the Common European Asylum System and Alternatives to Dublin. Brussels: European Parliament. Available at: https://goo.gl/uS3C5t. 
Guild, E., Costello, C., Garlick, M., Moreno-Lax, V., Mouzourakis, M. and Carrera, S. (2014). New Approaches, Alternative Avenues and Means of Access to Asylum Procedures for Persons Seeking International Protection. Brussels: European Parliament. Available at: https://goo.gl/2xCThh.

Hailbronner, K. (1993). The Concept of 'Safe Country' and Expeditious Asylum Procedures: A Western European Perspective. International Journal of Refugee Law, 5, 31-65. Available at: https://doi.org/10.1093/ijrl/5.1.31.

Hathaway, J. (2011). E.U. Accountability to International Law: The Case of Asylum. Michigan Journal of International Law, 33 (1), 1-7.

— and Neve, R. A. (1997). Making International Refugee Law Relevant Again: A Proposal for Collectivized and Solution-Oriented Protection. Harvard Human Rights Journal, 10, 115-211.

Hruschka, C. (2016). Enhancing efficiency and fairness? The Commission proposal for a Dublin IV Regulation. ERA Forum, 17, 521. Available at: https:/doi. $\operatorname{org} / 10.1007 / \mathrm{s} 12027-017-0451-\mathrm{x}$.

_ and Maiani, F. (2016). Comment to Regulation (EU) No 607/2013. In K. Hailbronner and D. Thym (eds.). EU Immigration and Asylum Law. A Commentary, $2^{\text {nd }}$ ed. (pp. 1478-1604). München/Oxford/Baden-Baden: C.H. Beck/ Hart/Nomos. Available at: https://doi.org/10.5771/9783845259208-1479.

Human Rights Council. (2015). Report of the Special Rapporteur on the human rights of migrants: Banking on mobility over a generation: follow-up to the regional study on the management of the external borders of the European Union and its impact on the human rights of migrants. Geneva: United Nations, Human Rights Council.

Hurwitz, A. (1999). The 1990 Dublin Convention: A Comprehensive Assessment. International Journal of Refugee Law, 11, 646-677. Available at: https://doi. org/10.1093/ijrl/11.4.646.

ICF International. (2015). Evaluation of the Dublin III Regulation. Final Report. Brussels: European Commission. Available at: https://goo.gl/de1wZQ. (2016). Evaluation of the Implementation of the Dublin III Regulation. Final Report. Brussels: European Commission. Available at: https://goo.gl/7vdTXC.

Kalkmann, M. (2015). AIDA Country Report: Germany, November 2015. Brussels: Asylum Information Database (AIDA). Available at: https://goo.gl/fcyNtm.

Karageorgiou, E. (2016). The Law and Practice of Solidarity in the CEAS: Article 80 TFEU and its Added Value. Stockholm: Swedish Institute for European Policy Studies. Available at: https://goo.gl/KYSrzs.

Klug, A. (2014). Strengthening the Protection of Migrants and Refugees in Distress at Sea through International Cooperation and Burden-Sharing. International Journal of Refugee Law, 26, 48-64. Available at: https://doi.org/10.1093/ijrl/ eeu008.

Küçük, E. (2016). The Principle of Solidarity and Fairness in Sharing Responsibility: More than Window Dressing? European Law Journal, 22, 448-469. Available at: https://doi.org/10.1111/eulj.12185. 
Kumin, J. (2015). Welcoming Engagement: How Private Sponsorship Can Strengthen Refugee Resettlement in the European Union. Brussels: Migration Policy Institute Europe. Available at: https://goo.gl/Gr1Lqh.

Lagarde, P. (1986). Le principe de proximité dans le droit international privé contemporain. Coursgénéral de droit international privé. Collected Courses of the Hague Academy of International Law, 186, 194.

Lambert, H. (1995). Seeking Asylum: Comparative Law and Practice in Selected European Countries. Dordrecht: M. Nijhoff.

Maiani, F. (2016a). The Dublin III Regulation: A New Legal Framework for a More Human System? In V. Chetail et al. (eds.). Reforming the Common European Asylum System. The New European Refugee Law (pp. 99-142). Leiden: Brill/ Nijhoff. Available at: https://doi.org/10.1163/9789004308664_006.

— (2016b). The Reform of Dublin III Regulation. Brussels: European Parliament. Available at: https://goo.gl/TaVqgp.

- (2017). The reform of the Dublin-system and the dystopia of "sharing people". Maastricht Journal of European and Comparative Law, 24, 622-645. Available at: https://doi.org/10.1177/1023263X17742815.

and Vevstad, V. (2010). Distribution of Applicants for International Protection and Protected Persons. In P. de Bruycker et al. (eds.). Setting up a Common European Asylum System: Report on the application of existing instruments and proposals for the new system. Brussels: European Parliament. Available at: https:// goo.gl/SMFjHw.

Marinai, S. (2016). The Interception and Rescue at Sea of Asylum Seekers in the Light of the New EU Legal Framework. Revista de Derecho ComunitarioEuropeo, 55, 901-939. Available at: https://doi.org/10.18042/cepc/rdce.55.04.

Milanovic, M. (2011). Extraterritorial Application of Human Rights Treaties. Oxford: Oxford University Press. Available at: https://doi.org/10.1093/acprof:oso/9780199696208.001.0001.

Mills, A. (2014). Rethinking Jurisdiction in International Law. British Yearbook of International Law, 84, 187-239. Available at: https://doi.org/10.1093/bybil/ bru003.

Milner, J. (2016). When norms are not enough: Understanding the principle and practice of burden and responsibility sharing for refugees. Geneva: Centre for International Governance Innovation. Available at: https://goo.gl/uyqafr.

Mitsilegas, V. (2017). Humanizing solidarity in European refugee law: the promise of mutual recognition. Maastricht Journal of European and Comparative Law, 24, 721-739. Available at: https://doi.org/10.1177/1023263X17742817.

Moreno-Lax, V. (2015). The Legality of the "Safe Third Country" Notion Contested: Insights from the Law of Treaties. In G. Goodwin-Gill and P. Weckel (eds.). Migration \& Refugee Protection in the 21st Century: Legal Aspects (665721). Leiden/Boston/The Hague: Academy of International Law Centre for Research/Brill/Nijhoff. 
- (2017). Solidarity's Reach: Meaning, Dimensions, and Implications for EU (External) Asylum Policy. Maastricht Journal of European and Comparative Law, 24, 740-762. Available at: https://doi.org/10.1177/1023263X17742338.

— and Papastavridis, E. (eds.). (2016). 'Boat Refugees' and Migrants at Sea: A Comprehensive Approach. Integrating Maritime Security with Human Rights. Leiden: Brill/Nijhoff.

Morgades-Gil, S. (2017). Forced Migration Management and the Right to Access to an Asylum Procedure inthe Area of Freedom, Security and Justice: Human Rights Between Responsibilityand Solidarity. Freedom, Security \& Justice: European Legal Studies, 1, 125-144. Available at: https://goo.gl/MhXSKt.

Morgese, G. (2014). Solidarietà e ripartizione degli oneri in materia di asilo nell'Unione Europea. In G. Caggiano (ed.). I percorsi giuridici per l'integrazione. Migranti e titolari di protezione internazionale tra diritto dell'Unione e ordinamento italiano (pp. 365-405). Torino: Giappichelli.

(2017). Principio di solidarietà e proposta di rifusione del regolamento Dublino. In E. Triggiani et al. (eds.). Dialoghi con Ugo Villani (pp. 471-476). Bari: Cacucci.

Morozzo della Rocca, P. (2017). I due Protocolli d'intesa sui "corridoi umanitari" tra alcuni enti di ispirazione religiosa ed il Governo ed il loro possibile impatto sulle politiche di asilo e immigrazione. Diritto immigrazione e cittadinanza, 19 (1). Available at: https://goo.gl/3YHZ4N.

Mouzourakis, M. (2014). 'We Need to Talk about Dublin'. Responsibility under the Dublin System as a blockage to asylum burden-sharing in the European Union. Oxford: Refugee Studies Centre. Available at: https://goo.gl/JC3Ams.

Nascimbene, B. (2016). Refugees, the European Union and the 'Dublin System'. The Reasons for a Crisis. European Papers, 1 (1), 101-113. Available at: https:// goo.gl/iXSGvz.

Noll, G. (2002). Protection in a Spirit of Solidarity? In R. Byrne et al. (eds.). New Asylum Countries? Migration Control and Refugee Protection in an Enlarged European Union (pp. 305-324). The Hague: Kluwer Law International.

— (ed.). (2005). Explaining Credibility Assessment in the Asylum Procedure. Leiden: Martinus Nijhoff.

Oxman, B. H. (2007). Jurisdiction of States. Max Planck Encyclopaedia of Public International Law. Oxford: Oxford University Press.

Parisciani, E. (2015). Search and rescue operations in the Mediterranean Sea and access to asylum: another "Dublin"? Journal of Immigration, Asylum and Nationality Law, 29 (2), 158-170.

Parusel, B. and Schneider, J. (2017). Reforming the Common European Asylum System: Responsibility-sharing and the harmonization of asylum outcomes. Stockholm: Delmi Report. Available at: https://goo.gl/zdXL6i.

Peers, S. (2012). Transfer of International Protection and European Union Law. International Journal of Refugee Law, 24, 527-560. Available at: https://doi. org/10.1093/ijrl/ees038. 
(2015). The Dublin III Regulation. In S. Peers et al. (eds.). EU Immigration and Asylum Law (Text and Commentary). Volume 3: EU Asylum Law (pp. 345-428). Leiden/Boston: Brill/Nijhoff.

Pollet, K. (2016). A Common European Asylum System under Construction: Remaining Gaps, Challenges and Next Steps. In V. Chetail et al. (eds.). Reforming the Common European Asylum System. The New European Refugee Law (pp. 74-97). Leiden/Boston: Brill/Nijhoff. Available at: https://doi. org/10.1163/9789004308664_005.

Pro Asyl et al. (2013). Allocation of refugees in the European Union: for an equitable, solidarity-based system of sharing responsibility. Available at: https://www.proasyl. de.

Reneman, M. (2013). Speedy Asylum Procedures in the EU: Striking a Fair Balance Between the Need to Process Asylum Cases Efficiently and the Asylum Applicant's EU Right to an Effective Remedy. International Journal of Refugee Law, 25, 717-748. Available at: https://doi.org/10.1093/ijrl/eet055.

Rossi, E. (2017). Superseding Dublin: The European asylum system as a non-cooperative game. International Review of Law and Economics, 51, 50-59. Available at: https://doi.org/10.1016/j.irle.2017.06.003.

Shaw, M. N. (2008). International Law (6 ${ }^{\text {th }}$ ed.). Cambridge: Cambridge University Press. Available at: https://doi.org/10.1017/CBO9780511841637.

Thielemann, E. (2018). Why Refugee Burden-Sharing Initiatives Fail: Public Goods, Free-Riding and Symbolic Solidarity in the EU. Journal of Common Market Studies, 56, 63-82. Available at: https://doi.org/10.1111/jcms.12662.

Thym, D. (2016). The "refugee crisis" as a challenge of legal design and institutional legitimacy. Common Market Law Review, 53, 1545-1574.

Tsourdi, E. (2017). Solidarity at work? The prevalence of emergency-driven solidarity in the administrative governance of the Common European Asylum System. Maastricht Journal of European and Comparative Law, 24, 667-686. Available at: https://doi.org/10.1177/1023263X17742801.

UNHCR. (1979). Executive Committee Conclusion No. 15 (XXX), Refugees Without an Asylum Country. Available at: https://goo.gl/JydErf.

— (1994). Position on Readmission Agreements, 'Protection Elsewhere' and Asylum Policy. Available at: https://goo.gl/wabLqe.

(2011a). Handbook on Procedures and Criteria for Determining Refugee Status under the 1951 Convention and the 1967 Protocol relating to the Status of Refugees. Available at: https://goo.gl/3CVCcw.

- (2011b). Refugees and Asylum-Seekers in Distress at Sea. How best to respond? Background Paper for the Expert Meeting in Djibouti (8-10 November 2011). Available at: https://goo.gl/ThKRCW.

(2013). Beyond Proof. Credibility Assessment in EU Asylum Systems. Brussels. Available at: https://goo.gl/ons1Mr.

- (2015). UNHCR Proposals to address current and future arrivals of asylum-seekers, refugees and migrants by sea to Europe. Available at: https://goo.gl/FQ1PAq. 
- (2016). Stabilizing the Situation of Refugees and Migrants in Europe. Proposals to the Meeting of EU Heads of State or Government and Turkey on 7 March 2016. Available at: https://goo.gl/yvuBWe.

_ (2017a). General legal considerations: search-and-rescue operations involving refugees and migrants at sea. Available at: https://goo.gl/V11 eyK.

— (2017b). Left in Limbo: UNHCR Study on the Implementation of the Dublin III Regulation. Available at: https://goo.gl/1Qh4uL.

Vanheule, D., van Selm, J., Boswell, C. and Ardittis, S. (2011). The Implementation of Article 80 TFEU - on the Principle of Solidarity and Fair Sharing of Responsibility, Including its Financial Implications, between the Member States in the Field of Border Checks, Asylum and Immigration. Bruxelles: European Parliament. Available at: https://goo.gl/HEDav3.

Vedsted-Hansen, J. (2016). Reception conditions as Human Rights: Pan-European Standard or Systemic Deficiencies? In V. Chetail et al. (eds.). Reforming the Common European Asylum System. The New European Refugee Law (pp. 317-352). Leiden/Boston: Brill/Nijhoff. Available at: https://doi. org/10.1163/9789004308664_012.

Vischer, F. (2011). Connecting factors. In K. Lipstein (ed.). Private International Law. International Encyclopedia of Comparative Law. Tübingen/Leiden/Boston: Mohr Siebeck/Martinus Nijhoff.

Vitiello, D. (2016). Du vin vieux dans de nouvelles outres? Réflexions sur la proposition de règlement «Dublin IV». European Papers, 1 (3), 1235-1251. Available at: https://goo.gl/dYq8NB.

Von Mehren, A. T. (2002). Theory and practice of adjudicatory authority in private international law: A comparative study of the doctrine, policies and practices of common- and civil-law systems. Collected Courses of the Hague Academy of International Law, 295, 9-432.

Wagner, M., Dimitriadi, A., O’Donnell, R., Kraler, A., Perumadan, J., Schlotzhauer, J. H., Simic, I. and Yabasun, D. (2016). The Implementation of the Common European Asylum System. Brussels: European Parliament. Available at: https:// goo.gl/op4qrs.

Wall, P. (2017). A New Link in the Chain: Could a Framework Convention for Refugee Responsibility Sharing Fulfil the Promise of the 1967 Protocol? International Journal of Refugee Law, 29 (2), 201-237. Available at: https://doi. org/10.1093/ijrl/eex025.

Williams, R. (2015). Beyond Dublin: A Discussion Paper for the Greens/EFA in the European Parliament. Brussels: The Greens/European Free Alliance. Available at: https://goo.gl/aYL8z3.

Yahyaoui Krivenko, E. (2012). Hospitality and Sovereignty: What Can We Learn From the Canadian Private Sponsorship of Refugees Program? International Journal of Refugee Law, 24, 579-602. Available at: https://doi.org/10.1093/ijrl/ ees039. 